\title{
The intermediate state in Paul
}

\author{
NSL Fryer
}

\begin{abstract}
The intermediate state in Paul

The point of view taken in this paper is that the apostle Paul envisions, between death and the resurrection of the body at the Parousia, an interim period during which the disembodied soul is in the immediate presence of Christ, though in a state of 'nakedness'. The background of Paul's view lies neither in contemporary Hellenistic religious-philosophical speculations nor in 'late-Judaism'. Two crucial 'forces' in particular moulded his perspective, viz the teachings of Jesus and His own rapture to 'Paradise'.
\end{abstract}

\section{INTRODUCTION}

1.1 The idea of the continued existence of the soul after death was in itself nothing new in the Hellenistic world of Paul's time. The thought of an 'underworld' (Hadès) where departed spirits dwell, was as familiar to the Greek mind as to the Hebrew. In Homer already there was the belief that the soul had a shadowy existence of its own after death, although far inferior to life on earth (Stacey 1956: 59; cf Nilsson 1949: $137 \mathrm{ff})$.

The thought of an intermediate state seemed to have developed in early Orphism. Orphism brought in some altogether new ideas in the sixth century $\mathrm{BC}$.

These included, (a) a new body/soul dualism. Man's soul came to be regarded as pre-existent, a spark of the divine, and as such immortal. Body and soul were distinct and separable. The body was a kind of prison-house (cf sōma sēma), where the soul was incarcerated as a punishment for previous sin (Guthrie 1966: 156f). This body/soul dualism became one of the most significant characteristics of the Greek view of man. Orphism influenced the Pythagoreans, Plato, Heraclitus, and the Stoics. Though Orphism itself did not regard the body as evil (Alderink 1981: 83), in later times, the body was disparaged by many. Thus, the Epicureans had no use for the body; and Stoicism despised it; (cf Ac 17: 18). Seneca, the Stoic, calls the body a 'corpus putre', a 
'hospitium breve' of the soul, an 'animi pondus ac poena'; the day of death is the 'aeterni natalis' of the soul (cited in Sizoo 1923: 295). (b) The transmigration of souls. The restoration of the soul to its original purity could not be effected in a single lifetime. The soul had to continue to undergo a series of reincarnations until it could purify itself so completely that it might rejoin the universal spirit (Guthrie 1950: 34ff; Stacey 1956: 62f). From Pythagoras these Orphic elements entered into Plato's philosophy and 'through Plato into most later philosophy that was in any degree religious' (Russell 1954: 37). (c) The conception of the abode of the dead underwent a progressive development (Cumont 1949: 189f). Four stages may be distinguished in that development: (i) At first the realm of the dead is regarded to be on earth. The tomb is the 'eternal abode' of the departed spirits (Van der Leeuw 1933: 297). (ii) At the next stage the underworld (Hadēs) is regarded as the 'all-inclusive undifferentiated' (Glasson 1961: 33) abode of all the dead, good and bad alike. (iii) Next, a division was made in Hadēs itself. The Orphics were first to separate in Hades the abode of the wicked (Hadês-Tartarus) from the abode of the blessed (Hades-Elysium) (Cumont 1922:171; Ubbink 1917: 51). (iv) In the final stage the souls of the blessed dead no longer descended to Hades-Elysium, but ascended to the celestial regions at death (Glasson 1961: 33; Hahnhart 1966: 14; Ubbink 1917: 52ff).

Stages (iii) and (iv) are especially significant. Glasson points out that we have a parallel development of thought in Jewish apocalyptic writings, a 'coincidence' which he regarded as 'hardly accidental' (1961: $33 \mathrm{f}, 38 \mathrm{ff}$ ). Of course, there also existed significant differences (cf Gundry 1976; Lincoln 1981; Stacey 1956). Further the conception of the transmigration of souls implied a belief in an 'intermediate state'. 'In early Orphism,' writes Glasson, 'while all souls go to the underworld at death this is only for a limited period, and the awaiting for a further experience of earthly life may be termed an intermediate state' (1961: 33).

Paul's use of expressions and metaphors which can be paralleled in current Hellenistic religious-philosophical speculations have convinced many scholars that he also took over the related religious conceptions. We shall address this problem in the exegesis below.

1.2 The nature of Paul's indebtedness to 'late-Judaism' is not easy to establish with certainty. It is uncertain if and to what extent he was acquainted with parallel conceptions and expressions in apocalyptic and pseudepigraphic writings. If he was acquainted with them it is 
uncertain to what extent he was affected by them. Again, there exists in these writings a great variety of speculations pertaining to the interim state. Often there is no question of unanimity. In our discussion below we shall investigate some of the relevant parallels.

1.3 Even a casual comparison shows remarkable points of correspondence between Jesus' teaching on the intermediate state and Paul's. For instance, the term Paradise is found, besides Revelation 2: 7, only with Jesus (Lk 23: 43) and in Paul (2 Cor 12: 4), in statements which bear some important similarities. Jesus' logion before the Sanhedrin (Mk 14: 58) contains a few expressions that again appear in a somewhat related context in 2 Corinthians 5: 1. Paul's words in Philippians 1: 23 bear clear resemblances to Jesus' logion to the penitent thief on the Cross ( $\mathrm{Lk} 23$ : 43), but does not go beyond it. The apostle's use of the metaphor of the dead as 'asleep' is best understood in the light of Jesus' own saying in Mark 5: 39 and parallel passages. Even a passage like 2 Corinthians 12: 1-4 which constitutes a crucial background to Paul's insight into the intermediate state, does not go beyond Jesus' own utterances in Luke 16: $19-31$.

The close connection between Paul and Jesus is almost entirely disregarded in modern exegetical discussions. Yet on all essential points Paul echoes, as it were, Jesus' own teaching without going beyond it in any significant respect.

1.4 In our discussion below we shall first go into a few Synoptic passages which may reflect Jesus' conception of the intermediate state, namely Matthew 22: 32; Luke 16: 19-31; 23: 43; and elsewhere in the paper also Mark 5: 39 and parallel passages. Then we shall turn to some relevant Pauline passages, namely 2 Corinthians 5: $1-10 ; 12$ : $1-4$; Philippians 1: 23; and 1 Thessalonians 4: 13. Our discussion must necessarily be relatively brief.

\section{JESUS AND THE INTERMEDIATE STATE}

\subsection{Matthew 22: 32}

According to Josephus, the Sadducees 'take away the belief in the immortal duration of the soul' (JosBJ 2, 8, 14); they believed 'That souls die with the bodies' (JosAnt 18, 1,4). Such a view of death leaves no 
room for a belief in an afterlife or resurrection of the dead (cf Mt 22: 23; Lk 20: 27; Ac 23: 8).

Jesus ascribes their erroneous views to the fact that they 'know neither the scriptures nor the power of God' (v 29). God's self-revelation to Moses 'in the passage about the bush' (Mk 12: 26) contains in it the seed of continued existence and the hope of resurrection (cf Alford 1958a: 223; Wohlenberg 1910: 317f). Abraham, Isaac and Jacob 'wäre ja die drei "Väter", mit denen Gott als mit Repräsentanten des Judentums seinen Bund geschlossen hatte' (Odeberg 1938: 191,5f). His covenant relationship with these partriarchs is both personal and everlasting. Isaac became a covenant party after the death of Abraham, and Jacob after Isaac's death. Yet, God, in revealing Himself to Moses as 'I am the God of Abraham, and the God of Isaac, and the God of Jacob' (Mt 22: 32a), speaks to Moses 'as if they were comtemporary with each other or with Moses' (Hill 1972: 305). The inference is obvious: Jesus 'declares their continuance' as the other parties of the covenant (Alford 1958a: 224f). Though their bodies are dead, these patriarchs are still alive beyond the grave (Cole 1961: 191; Geldenhuys 1951: 224f; Grosheide 1922: 265; Morris 1974: 292), for 'He is not the God of the dead but of the living' (v 32b).

This very fact that 'He is not the God of the dead, but of the living' is the fact in which God's power is manifested, but which the Sadducees did not 'know'. For that divine utterance to Moses could not have been made of 'non-existent beings' (Morris 1974: 292; cf Godet sa: 248; Swete 1909: 282; Zahn 1910: 642f), nor of souls 'asleep' in the intermediate period (Alford 1958a: 225).

Some commentators argue that the language used 'does not necessarily imply that they are alive' (Taylor 1952: 484); or again, that they are only alive "'from God's perspective" or, proleptically, "in the prospect of sure resurrection"' (Ellis 1960: 235; Marshall 1978: 742). But this is to disregard the theological issue involved in the question of the Sadducees. Further, the impression is created that the multitudes were 'astonished' ( $v$ 33) precisely because they understood the implications of Jesus' logion in verse 32, namely that the patriarchs are still alive. Ellis raises two objections: (a) that the view advocated here 'assumes a body/soul dualism that is ... uncharacteristic of the New Testament view of Man'; and (b) that it is contrary to the context, because 'If Abraham is now personally "living", no resurrection would be necessary for God to be "his God"' (1974: 235). But neither objection is valid. For, as to (a), the body/soul duality against which Ellis objects, seems to 
be precisely the one which Jesus upheld over against the Sadducees (cf Lk 8: 49b, 54, 55; Lk 16: 19-31; 23: 43). As to (b), real life in Biblical sense is life in body and soul alike. Body and soul are both true part of man. For this reason 'the resurrection from the dead' (cf Lk 20: 35) is essential.

Jesus' reply thus includes two crucial implications. One, that the resurrection from the dead' is still a future event for the patriarchs (Grundmann 1973: 249; contra Lohmeyer 1963: 257); and, two, that the patriarchs have, nevertheless, ever been alive beyond the grave, enjoying in a disembodied state communion with the God of the covenant.

\subsection{Luke 16: 19-31}

The parable speaks 'vom Zustand nach dem Tode ( $u$ nicht vom Zustand nach dem Endgericht)' (Jeremias 1954: 767 n37). This is evident from (i) the placing of the resurrection in the future (v 31); (ii) the use of expressions such as 'to Abraham's bosom' (v 22), and 'Hadēs' (instead of 'Gehenna') (v 23); and (iii) contemporary Jewish beliefs (eg TAb 20A) (Gundry 1976: 105, 114; Jeremias 1954: 767 n37).

The expression eis tòn kólpon Abraám which can be parallelled from rabbinic literature (Meyer 1938: 725, and n8) must obviously be taken figuratively (Geldenhuys 1951: $428 \mathrm{n} 7$ ). It does not refer to a literal reclining at table at Abraham's side (Zahn 1913: $586 \mathrm{n} 16$ ). The picture is that of rest 'von der Mühe und Not des Erdenlebens in Trauter Gemeinschaft mit dem im Tode noch lebenden und seligen Stammvater' (Zahn 1913: 586 n16; cf Meyer 1938: 825, 6ff). As such, 'Abraham's bosom' is neither a part - for example 'the happy side' (so Alford 1958a: 603) - of Hadess, set apart for the righteous dead (Manson 1949: 299; Strack \& Billerbeck 1924: 266f), nor is it a synonym for Paradise itself (Marshall 1978: 636). The phrase probably speaks of the state of the righteous dead immediately after death, and conveys the same thought as such Pauline expressions as 'be at home with the Lord' (2 Cor 5: 8), and 'to be with Christ' (Phlp 1: 23; cf Ac 7: 59; Jn 12: 26) (cf Jeremias 1954: 767, 2ff). Since Abraham was thought to be in Paradise (TAb 20A), 'Abraham's bosom' is most probably a rabbinic equivalent for enjoying fellowship with Abraham in Paradise immediately after death (Marshall 1978: 636; Robertson 1930: 222; Vincent 1957a: 398).

'Late-Judaism' saw a few significant developments in the conception of Hadès/Sheol (Strack \& Billerbeck 1955: 1016f). For instance: (a) Hadès, considered as 'the abode of all departed souls till the final judgement' 
(Charles 1913: 357) came to be regarded as consisting of two divisions: an abode of blessedness and rest for the righteous (WisSol 3: 1; cf JosAnt 18, 1,3), and a place of pain and torment for the wicked (1 En 22; 2 Bar 36: 11). The two divisions were considered adjacent to each other (1 En 22; 4 Ezr 7: 85, 93) (Charles 1913: 357; Jeremias 1933a: 147, 9ff; Strack \& Billerbeck 1924: 228). (b) A further development led to the conception that the souls of the righteous entered into the heavenly realms immediately at death there to wait in bliss until the resurrection (Jeremias 1933a: 147, 14ff; cf Sjöberg 1959: 377, 11ff). According to Josephus the Pharisees held conception (a) (JosAnt 18, 1, 3; JosBJ 2, 8, 14), whereas he himself accepted (b) (JosBJ 3, 8, 5).

The New Testament view of Hadess corresponds closely with that of contemporary Judaism. But some crucial differences exist: (a)the New Testament makes a sharp distinction between Hadess and Gehenna. Hadès is the temporary abode of the wicked dead, in disembodied form, during the intermediate period only (Jeremias 1933a: 149, 34ff). Gehenna is the final place of punishment for the wicked in their resurrection bodies (cf Mt 5: 22, 29, 30; 10: 28; 25: 41) (Jeremias 1933c: 655, 34ff). (b) Nowhere in the New Testament is it intimated that those who have died in Jesus, first go to Hades (Geldenhuys 1951: $429 \mathrm{n} 9$ ). In a few instances Hades still carries the Old Testament/late-Judaistic idea of Totenwelt in general, a temporary place, where all souls go immediately at death (Ac 2: 27, 31; cf 2 Bar 23: 5; 48: 16; 51:2). Other passages regard Hadès as the intermediate abode of the wicked alone (Lk 16: 23-31; $1 \mathrm{Pt}$ 1:18; Rv 1: 18; 20: 13, 14). In Luke 16: 22, 23 only the rich man appears to be in Hadès (Cremer 1895: 69); Marshall 1978: 637; contra Vincent 1957a: 94). Abraham and Lazarus are 'far away' (v 23) and separated from himself by a 'great chasm' (v 26). But 'no Jewish writings view Paradise or Abraham to be part of the "underworld"' (Ellis 1974: 206; cf Jeremias 1954: 768 n52; Zahn 1913: $704 \mathrm{f}$ and n20). The 'great chasm' apparently separates 'between Hadēs and the heavenly realms' (Ellis 1974: 206; cf Bruce 1970: 589). (c) The New Testament view of Hades is closely linked with the person and work of Christ. He has the 'keys of death and of Hadès' (Rv 1: 18). Those who 'die in the Lord' (Rv 14: 13) are with Him immediately at death (Lk 23: 43; 2 Cor 5: 8; Phlp 1:23). The intermediate abode of the faithful is now identified as 'the eternal dwellings' (Lk 16: 9), 'in Paradise' (23: 43), 'at home with the Lord' (2 Cor 5:8), 'with Christ' (Phlp 1: 23), 'the heavenly Jerusalem' (Heb 12:22) (cf Jeremias 1933a: 149, 9ff). Jesus' view of Hadēs and Paradise excludes 
altogether any idea of a 'soul-sleep' of the dead during the intermediate state.

In conclusion, we assume that we have here to do with a parable and not with a real occurrence (cf Geldenhuys 1951: $428 \mathrm{n} 5$ ). We also assume that the things Jesus actually said 'were not contrary to His own belief' (Ward 1943: 237; Alford 1958a: 602). The whole thrust of vv 27-31 would be pointless if in the preceding verses (22-6) Jesus had assumed (concerning the 'intermediate state') as existing, anything which does not exist.

Three basic things about the intermediate state emerge from the parable: (a) Jesus recognizes that at the moment of death, in ipso articulo mortis, man's 'soul' goes forthwith, either to the abode of the wicked (Hadess) (v 23), or to the abode of the righteous ( $v 22$ ). (b)These two abodes are envisioned as situated adjacent to, yet 'far away' (v 23) from, each other, and as separated by 'a great chasm' ( $v$ 26), so that the one cannot go over to the other ( $v 26$ ). The abode of the righteous dead ('Paradise') is not part of Hadēs, as we have argued above. (c) Both in Hades and in Paradise existence is on a wholly conscious level. For instance, the rich man's soul could 'lift up his eyes', was 'in torment', 'saw Abraham far away, and Lazarus in his bosom' (v 23), 'cried out' and pleaded for mercy ( $v$ 24), had memory of his earthly relations (v28), and interceded for his brothers ( $v 27$ ), knowing that they were in need of repentance ( $v$ 30). Jesus knows nothing of a 'soul-sleep' or a semi-conscious form of existence between death and the resurrection.

Jesus' teachings here are not altogether peculiar to this Parable. On all points they can be paralleled from contemporary Judaism. In addition, the basic views reflected in the Parable are found elsewhere in the teaching of Jesus (cf Mt 22: 32; Lk 23:43; Mk 5: 39) and of Paul (cf 2 Cor 5: 1-10, 12: 1-4; Phlp 1: 23) as well.

\subsection{Luke 23: 43}

The meaning of the logion rests upon the interpretation of the three expressions: sēmeron, met' emồ ésē and en tō paradeisō.

It is doubtless that semeron belongs with the second clause (cf Zahn 1913: $703 \mathrm{n} 18$ ) where it stands in a place of emphasis (Zahn 1913: $705 \mathrm{n}$ 22). It is here not 'a technical expression for the time of Messianic salvation' referring to Jesus' 'exaltation and resurrection' (contra Ellis 1974: 268; Baird 1971: 704). In the context 'today' speaks of the very day of crucifixion as the day of entry into Paradise (Greijdanus 1941: 1149; 
Marshall 1978: 873; Zahn 1913: 704). The repenting thief requested Jesus to 'remember' him, that is, at the resurrection (Ellis 1974: 268; Geldenhuys 1951: 611). Jesus assured him, 'nicht erst am Ende der Tage, sondern binnen weniger Stunden, heute noch, soll er mit Jesus im Paradies sein' (Zahn 1913: 705). Further, Jesus will not only 'think' of him; he will be in the very presence and company of Jesus in Paradise (cf met' emoû) (Greijdanus 1941: 1149).

The term parádeisos (Jeremias 1954: 763ff) was used in the LXX for the Paradise of Adam (Gn 2;3). It then became a type of the future bliss of the people of God (Is 51: 3; cf Ezk 36: 35). It came to be used in a technical sense first in TLevi 18: 10f (cf 4 Ezr 8: 52). Pre-Christian apocalyptic identified the primal Paradise with the Paradise of the end, thus leading to the conception that it existed in hidden form between the creation and the end (TLevi 18: 10f; TDan 5: 12; 1En 25: 4f) (Bultmann 1976: 223f; Jeremias 1954: 764, 21ff and n16; Strack \& Billerbeck 1926: 533f). In 'late-Judaism' it came to be regarded without exception as the intermediate abode for the souls of the righteous dead, for example the patriarchs (1En 70:4; TAb 20A), and other elect and righteous men (eg 1En 60: 8, 23; 61: 12; 70: 4); (cf Strack \& Billerbeck 1926: 534) like Enoch and Elijah, who did not die (eg 1En 60: 8; 70: 3, Jub 4:23) (cf Bietenhard 1969: 998; Zahn 1913: 704f). The same idea is found in Lk 23: 43. Paradise is here 'die Stätte, die Seelen der verstorbenen Gerechten nach dem Tod aufnimmt, also das verborgene (zwischenzeitliche) Paradies ...' (Jeremias 1954: 768, 29ff; Greijdanus 1941: 1149; Robertson 1930: 287; Vincent 1957a: 437; Zahn 1913: 704f). In v 43 Jesus says nothing about the location of Paradise. But it should not be located in Hades in order to avoid a contradiction with assertions on Christ's descent into Hadēs (contra Mattill 1979: 34; H H Wendt, cited in Jeremias 1954: $768 \mathrm{n}$ 52). For in 'late-Judaism' Paradise is never envisaged as a part of Hadēs (Ellis 1974: 206; Jeremias 1954: 768 n52; Strack \& Billerbeck 1924: 227; Zahn 1913: 704f and n20).

We conclude: (a) Jesus unmistakably declares that death is not the end for man. The soul continues to exist in a separate disembodied state when the body is dead. (b) There is no reason to take either Jesus' reference to the state ('with $\mathrm{Me}^{\text {') }}$ or the place ('in Paradise') in any other sense than the literal. (c) This logion of Jesus seems to have been seminal to Paul's understanding of the intermediate state, both regarding its location in Paradise and the sober manner of describing the condition itself. In essential teaching Paul does not go beyond Luke 23: 43 in either 2 Corinthians 5: 8, or 12: 2ff, or Philippians 1: 23. 


\section{PAUL ON THE INTERMEDIATE STATE}

\subsection{Corinthians 5: $1-10$}

The wide variety of ways in which this passage has been understood, can be reduced by fairly common consent to some three basic lines of interpretation.

A first approach holds that there is here no room for an intermediate state of the dead; Paul's hope is fixed solely on the Parousia. Mundle (1927) thinks that the kataluthenai ( $\mathrm{v}$ 16) needs not be understood of death ( $p$ 96). The when of the ependúsasthai (=endusasthai) ( $p$ 101) is nowhere in view ( $p$ 97f). The gumnós ( $v$ 3) does not refer to a bodiless existence in the intermediate state, but gumnós 'ist darum jeder, der im Endzustand den Herrlichkeitsleib nicht erhält, also tatsächlich jeder Nichtchrist' ( $\mathrm{p}$ 101). Also the ekdēmēsai ek tôu sōmatos and the endēmēsai pròs tòn Kúrion ( $\mathrm{v} 8$ ) refer to the 'Endzustand nach der Parusie' ( $\mathrm{p} 106 \mathrm{f}$; cf also Oepke 1933: 774, 19ff; 1935: 318, 37-319, 14; 320, 20ff; 321, 17ff). For Brun (1929) the 'we' (v 1a) refers specifically to Paul as the typical representative of the suffering Glaubensboten ( $\mathrm{p} 216$ ). The kataluthenai does not refer to death 'im Buchstäblichen Sinne' but to 'dass Vollmass seiner Leiden und Bedrängnisse, der schon ausgestandenen und noch auszustehenden' (p 220). Also v 8 has reference to the Parousia (p 222). Ellis (1960) holds that in v 1 Paul's 'primary thought is not of individual bodies at all, but of corporate solidarities which inhere in Adam and in Christ, the old aeon and the new aeon' (p 217). Only at the Parousia death is swallowed up 'and all en Christo, shall "put on" immortality' ( $\mathrm{p}$ 218). Gumnós and ekdúsasthai (vv 2-4) express the wish not to stand 'in the Judgement en Adám, ie in the Body that is naked in guilt and shame' ( $p$ 221). Also in verse 8 there is no reference to the intermediate state ( $p$ 222). Yet another form of this basic motif is that of Reichenbach. Proceeding from a monistic view of man, Reichenbach concludes that 'the individual human person does not exist during this interim. He ceases to exist at his death, and begins again to exist at his re-creation' (1977: 38).

A second basic view contends that the blessed dead receive the resurrection body in articulo mortis. Scholars holding this view commonly presume that Paul's eschatology underwent a significant development between 1 and 2 Corinthians. Paul became conscious of inherent inconsistencies on his former view (1 Cor 15) and 'abandoned it in favour of the doctrine of a resurrection of the righteous immediately on death' (Charles 1913: 198, 458). For Knox 2 Corinthians 'is largely devoted to a complete revision of Pauline eschatology in a 
Hellenistic sense' (Knox 1939: 128). Hettlinger thinks that Paul is heir to a synthesis between Hellenism and Judaism (1957: 186), while Bultmann argues that in 2 Corinthians 5, Paul comes very close to Hellenistic Gnostic Dualism (Bultmann 1968: 201f). Windisch (1924), explicitly rejecting the view that the Parousia is in view in 2 Corinthians 5: 1-5 (p 161), thinks that the 'tent-house' (v 1) reflects Greek dualistic anthropology (p 158), the moment of the kataluthenai of the 'tent-house' is in typical Greek fashion the moment 'der Umzug in ein anderes Haus' ( $p$ 159); the fact that 'we have' this 'house from God' at death means 'es steht dann zu unserer Verfügung und existiert schon jetzt "im Himmel"' (p 160).

A third view holds that in the present passage Paul speaks of an intermediate state. According to the normal form of this view the 'building from God' $(\mathrm{v} 1,2)$ is the resurrection body of the believer; the word 'naked' ( $\mathrm{v} 3$ ) refers to a disembodied existence after death; and the being 'absent from the body' (v 8) means 'leaving our home in the body' (so eg Barrett 1973: 150ff; Bernard 1970: 65ff; Bruce 1971: 201ff; Hughes 1962: 160ff; Ridderbos 1975: 499ff). Here the expectation of an intermediate state 'hängt unvergänglich mit dem Glauben an die Auferstehung der Toten als ein einmaliges Gesamtereignis zusammen' (Sevenster 1955: 296).

A variety of divergent views are subsumed under this basic view: One of the best known is that of Oscar Cullmann (1958): the Bible only knows of man-as-a-whole. Man dies as a whole so that there is no separation of a 'soul' from the body at death ( $p$ 36ff). After death the whole man, soul and body, 'are still in time' ( $p$ 49) and waiting in the interim period in a condition of 'sleep' for the resurrection of the whole man ( $\mathrm{p} 48 \mathrm{ff}$ ). For those who possess the Spirit 'the separation from God in death . . . no longer exists'. For 'The "sleep" seems to draw them even closer to Christ' (v 8) (p 53).

\subsubsection{Some points of exegesis}

\subsubsection{The 'building from God' (v 1c) is the resurrection body}

Along with most commentators we take the term oikia in $\mathrm{v} 1 \mathrm{~b}$ as a metaphorical reference to the physical body of the believer (Bultmann 1963: 6; Harris 1974: 318; Hodge 1963: 112f). This is confirmed by (i) the inverted parallelism (chiasmus) of verse $1 \mathrm{~b}$ and $\mathrm{d}$ :
epígeios
hē oikia toû skénous
a oikian acheiropoíeton aiōnion
$\mathrm{b}$ en toîs ouranoîs 
The chiastic correlation between $b-b^{\prime}$ suggests that in both instances oikia must refer to physical embodiment. (ii) The idea of a 'habitation' in the physical body, whether in the 'tent-house' of verse $1 \mathrm{~b}$ or the 'building from God' of 1cd, is in or near the foreground throughout the passage. In vv 6-9 the imagery changes but the theme and basic concepts remain the same. At the same time the 'earthly tent-house' (1b) is explicitly identified as the soma: 'at home in'/'absent from' the body. (iii) The context points in the same direction. The 'outer man' (4: 16 ) is the same as the 'earthen vessels' (4: 7), 'the body' (v 10), and 'our mortal flesh' (v 11); it is taken up again by 'our earthly tent-house' in 5: 1 ; and describes man 'nach seiner physischen vergänglichen Seit' (Jeremias 1933b: 366, 12f).

Grosheide mistakenly subsumes everything under the key concept of existence ('bestaan'), and then takes 'earthly tent-house' ( $v$ 1b) as referring to 'het uiterlijke levensbestaan op aarde' (1959: 140). But, as Ridderbos rightly remarks, 'it is clear from the whole context that what is meant here is the temporal mode of existence of man in the earthly body' (emphasis mine) (1975: 500).

The kataluthenai of the 'earthly tent-house' can only refer to death (Bultmann 1976: 134) as in the few other occurrences of the related terms in Paul, namely analûsai (Phlp 1: 23) and análusis (2 Tm 4: 6). The aorist subjunctive cannot describe the process (contra Brun 1929: 216ff), but the momentary act of dying. Ean with the aorist subjunctive represents 'a definite event occurring only once in the future, conceived as taking place before the time of the action of the main verb. It is expectation not fulfilment as yet' (Turner 1963: 114f). The order is first the katálusis then the échein.

The two terms oikia (1d) and oikodome ('building') (1c) are synonymous. Verse $1 \mathrm{~d}$ stands in apposition to oikodome in 1c. The word oikodome signifying 'a permanent structure with foundations' (Hughes 1962: 163) stands in strong contrast to the 'earthly tent-house' (1b).

Robinson points out that whenever Paul uses the word oikodome "(except in the purely figurative sense of "edification"), it means the Body of Christ, the Church (1 Cor iii.9; Eph ii.21, iv.12, 16), not an individual body' (1952: 76; Ellis 1960: 217). This is true. But it is wrong to conclude from this that the term must consequently have an ecclesiastical meaning in 2 Corinthians 5: 1 as well. In the present context the term cannot refer to the Church (Borse 1972: 131): (i) Here the apostle is not concerned with the Church, but with the expectation of believers in the face of death. (ii) The oikodome $(1 \mathrm{c})$ (= to oikterion tò 
ex ourano $\hat{u}, \mathrm{v} 2$ ) is closer defined in 1cd by four adjuncts, viz ek theô, oikía acheiropoiettos, aiōnios and en toîs ouranoîs. The corresponds to the fourfold description of the soma pneumatikon (= the resurrection body) in 1 Corinthians 15: both are $e k$ theoû (cf 15: 38,42), akatálutos (cf 15: 42, 52-4), pneumatikós (cf 15: 44, 46), and epouránios (cf 15: 40-9) (cf Borse 1972: 132 n29; Harris 1974: 322; Rissi 1969: 80). The parallels are so close that it seems beyond doubt that Paul envisages an identical reality in both passages. 'Das Hause [V.1] ist also nichts anderes als das sōma pneumatikón von 1 Kor 15' (Rissi 1969: 80; Kennedy 1904: 265f).

This interpretation excludes among other views also the following: that the oikodome $e k$ theou is equivalent to 'heaven itself' (Cranford 1976: 99; Hodge 1963: 109ff; Tasker 1958: 77f); or to the heavenly life and existence' (Lenski 1937c: 1000; Grosheide 1959: 142); or, as Calvin puts it, to the 'beatus animae status post mortem' (Calvin, cited in Lang 1973: $17 \mathrm{n} 31)$.

\subsubsection{We receive this new body only at the Parousia}

In the word échomen itself is 'no reference to the detail of time' (Kennedy 1904: 265). It is obvious that échomen cannot refer to a strictly literal present possession of the 'spiritual body'. The reference can only be to some future possession. As a praesens pro indicativo the verb can refer to a possession of that body, (i) immediately after death (so eg LS Thornton, cited in Berry 1961: 62; Windisch 1924: 160) in which case an intermediate state needs not be implied; or (ii) at the Parousia. In this case the present tense conveys a 'tone of assurance' (Moulton 1908: 120; Rehkopf 1976: §323; Turner 1963: 63), and an intermediate state is clearly implied.

The meaning of échomen should be in accord with Paul's unambiguous teaching in other passages on the receiving of the 'spiritual body'. Now, since Paul's constant teaching is that the resurrection of the body only transpires en tē parousía tôे Christôि (1 Cor 15: 23; cf 1 Th 4: 16f; Phlp 3: 20f), the reference must be to that event. That this interpretation is the right one is confirmed by the following considerations: (i) Paul's view of death is inseparably linked with his expectation of the Parousia and the resurrection of the dead on that occasion. In the present passage his allusions to and direct statements concerning the intermediate state can only be properly understood against that background. (ii) Paul does not say that we have this 'building' 'forthwith' ('sofort' - Bultmann 1963: 7). The insertion of any such temporal qualification - for example 'nach dem Tod sofort' (Windisch 1924: 160; Charles 1913: 458f) - carries 
a foreign element into the text which is not required by the context (Mundle 1927: 96). (iii) The suggestion that we have a resurrection body ready-made at the moment of death (eg Charles 1913: 458f; Windisch 1924: 160), 'is to render unintelligible the inevitable prospect of "nakedness" which Paul holds out for those dying before the Parousia' (Robinson 1952: 77; Wendland 1978: 196). (iv) The view that we receive the resurrection body immediately upon death often proceeds from the mistaken assumption that Paul had suddenly changed his eschatological expectation between 1 and 2 Corinthians. But this is entirely improbable. If this had been true then he must have reverted to his earlier views after the writing of 2 Corinthians, since, as Rissi points out, 'er vor und nach dem 2. Kor eine durchaus einheitliche Eschatologie vorträgt' (1969: 84).

A fair conclusion would be that, although not explicitly stated in $\mathrm{v} 1$, the thought of an intermediate state is implicitly present. ' $W e^{\prime}$ are confident that when this mortal body 'is torn down' (NAS), we will receive our 'spiritual body' (=the resurrection body), but only at the Parousia. The implications of this basic assumption with reference to the interim period is described in verses $2-10$.

\subsubsection{The intermediate state is a condition of 'nakedness' of the soul (v 3, 4).}

Throughout the present passage we have an interaction of two metaphors, namely that of a 'habitation' (vv 1, 2, 4, 6, 8, 9), and a 'garment' (cf ekdúsasthai/ependúsasthai - vv 2, 3,4) both of which are directly linked with the physical body. Our present concern is with verse 3 in particular. In the context ei ge ( $\mathrm{v} 3$ ) is most probably = siquidem (cf Liddle \& Scott 1968: 481; Kühner-Gerth 1966: 178), expressing 'assurance rather than doubt' (Barrett 1973: 153; Jager sa: 97; Lenski 1937c: 1002), that is literally 'if indeed, which is assured' (Lenski 1937c: 1002; Jager sa: 97). The aorist participle endusámenoi (sic!) (along with eg Metzger 1971: 579f; Barrett 1973: 153; Rissi 1969: 8) describes the momentary act of 'putting on' the 'garment' (= the resurrection body) at the time of the Parousia (Barrett 1973: 153; Ridderbos 1975: 501f).

The word gumnós describes the condition of the blessed dead during the interim period between the 'putting off' (ekdúsasthai, v 4) of the 'earthly tent-house', the mortal body ( $\mathrm{v} 1 \mathrm{~b})$, and the 'putting on' (endusámenoi, $\mathrm{v} 3$ ) of the 'building from God', the resurrection body (v 1cd). The word 'naked' describes that condition as one of bodiless existence, 'like the souls in Sheol, without form, and void of all power 
of activity' (Plummer 1915: 147; Rissi 1969: 90; Robertson 1931: 228) - a notion abhorrent to Hebrew thought (Kennedy 1904: 266). In the Greek and Hellenistic philosophical thinking gumnós was frequently used of the disembodied soul; (see representative passages in Barrett 1973: 153f; Oepke 1933: 774, 8ff; Windisch 1924: 164f) and could well have been known in Corinth (cf Jager sa: 97). The term presupposes a body/soul anthropological duality that was common in contemporary Pythagorean and Platonic thought (cf Windisch 1924: 158f, 162), was known in late-Judaism (cf 4Ezr 7:78; ApMos 32: 4; WisSol 9:15), and was also found in the teaching of Jesus (eg Mt 22:32; Mk 5: 35, 39; Lk 16: 19ff; 23: 43). In the present passage as in Phlp 1: 23 (cf 2 Cor 12: 2) Paul, too envisions that the soul is separated from the body at death (Cassidy 1971: 215; Sevenster 1955: 296; Whiteley 1974: 256f). But although Paul uses here 'a quantity of Hellenistic language', he does not use it in its normal Hellenistic sense (Barrett 1973: 153). Thus gumnós 'hat bei Paulus einen ganz anderen sinn als bei Plato und Philo' (Sevenster 1955: 296). Paul did not despise mortal embodiment. The soma was the 'temple' (naós) of the Holy spirit (1 Cor 6: 19f; cf 3: 16). Nor did he long to be liberated from corporeality as such (Phlp 1: 21f). Further, for Paul the nakedness of the soul, that is disembodied existence, was not a desirable thing as in Hellenistic thought (2 Cor 5: 2ff).

Under the soteriological interpretation of gumnós the 'nakedness' is regarded as 'das endgültige Schicksal der Ungläubigen, für welche kein Himmelsleib bereit ist' (Oepke 1933: 774, 21f, 28f; cf Grosheide 1959: 145). 'Naked' means 'to be found without "a wedding garment"' (Ellis 1960: 43). But this view is unacceptable. For (i) throughout the passage Paul is concerned with the believers only (cf Bruce 1971: 206) and to drag into the picture the fate of the unbelievers would be a quite 'irrelevant idea' (Kennedy 1904: 266): (ii) taking endusámenoi (v 3) as 'clothed with the righteousness of Christ' (Grosheide 1959: 144f) would be a metabasis eis allo genos (Ridderbos 1975: $502 \mathrm{n} 43$ ); and (iii) it is impossible to associate with Paul the fear of being found 'naked' = 'guilty', 'reprobate' before God at the Parousia in view of 'everything he said on the subject of Justification' (Cassidy 1971: 215).

\subsubsection{The intermediate state is a condition of being 'away from the} body' and 'at home with the Lord' (v 8).

Some commentators refer verses 6-10 to the Parousia. Thus Hoffmann argues that verse $8 \mathrm{~b}$, in particular, should not be taken as a 'selbständige Aussage des Paulus über den Todeszustand' (1969: 281; 
Mundle 1927: 107). Ellis, considering it as 'probably a misconception' to identify 'away from the body' ( $\mathrm{v} 8 \mathrm{~b}$ ) with the intermediate state at all, suggested that 'away' should be understood 'merely as absence from the solidarities of the mortal body' (1960: 222). But the context points to the intermediate state: (i) No temporal distinction can be drawn between the kataluthènai of the earthly tent (v 1) and ekdemésai, ktl (v 8), relating the former to the time of death but the latter to the Parousia. Both the ekdèmia (of $\mathrm{v} 8$ ) and the katálusis (of $\mathrm{v} 1$ ) transpire at death. (ii) The two modes of existence, namely ekdēmein and endèmeîn are 'jeweils zwei in sich abgeschlossenen Seinswesen' (Grundmann 1935: 62, 44ff). The kai is explicative. The moment we 'leave' the body (at death) is the moment we 'come home' to the Lord (Barrett 1973: 159; Harris 1971: 46). This is confirmed by the context. In verse 6 the two states of existence are envisaged as coincident; in verse 8 'out of $(e k)$ the body' is equivalent to 'face-to-face-with (prós) the Lord'. The transition from the one state (verse 6) to the other (verse 8) comes about at the katalusis of 'our earthly tenthouse' (cf Lenski 1937c: 1012f). In verse 7 walking 'by faith' and seeing 'face to face' are considered two mutually exclusive and immediately successive modes of existence (Harris 1971: 46).

Paul describes the state and location of the blessed immediately after death, simply as endēmésai pròs tòn Kúrion. Some prefer to take the infinitive as an ingressive aorist, 'to take up residence' (Harris 1971: 46; cf Robertson 1931: 229) 'nach Hause gehen' (Grundmann 1935: 62, 35f). Emphasizing the ingressive aspect of the verb, some scholars maintain that prós with the accusative expresses only 'linear' motion, that is 'to', 'toward' (Furnish 1984: 274). If this is correct, then endemèsai pròs tòn Kúrion, contrary to sùn Christō einai (Phlp 1: 23), does not depict the state of the blessed dead, but simply the goal or direction after the verb of motion (so Furnish 1984: 274; Lang 1973: 192 n366). Others, however, prefer the 'more "punctiliar" sense' (Moule 1959: 52f; Moulton 1968: 467). Harris points out that the distinction between motion and rest has become obscured in Hellenistic Greek so that prós with the accusative, when used to indicate a relationship between persons, may mean simply 'with' 'in the presence of' (Harris 1971: 46; Robertson 1934: 625), and prós with the accusative is equivalent to parà tō Kuriō (Rehkopf 1961: §239(1)). Still others regard the phrase as a probable instance of 'that pregnant mode of thought which is characteristic of the Greek language' where the idea of 'linear' motion ('going to the Lord') is combined with that of 'punctiliar' rest ('being in His presence') (Hughes 1962: 178 n53). 
The phrase pròs tòn Kûrion evidently includes more than merely an indication of goal after a verb of motion. Philippians 1: 23, the closest parallel to verse 8 (Rissi 1969: 95; Schenk 1984: 154), apposes the view that only a notion of motion is included. What Paul has in mind is 'some heightened form of inter-personal communion' with Christ (Harris 1971: 46), even the 'face to face converse with the Lord' (Robertson 1934: 625), which can be experienced 'nur ausserhalb dieses leiblichen Seins' (Grundmann 1935: 62,43f) and which the blessed enter into in ipso articulo mortis. What is involved is a living relationship, an intimate converse with the Lord (Robertson 1934: 625), not merely 'corporate inclusion in Christ's "body" the Church' (contra Ellis 1974: 269), nor a condition of 'soul-sleep' (contra Cullmann 1958: 52ff).

3.1.1.5 The passage is silent on all other questions concerning the intermediate state. Paul depicts that state simply as being 'at home with the Lord' without any speculation about 'die Art und Weise dieses Seins' (Rissi 1969: 96; Cranford 1976; 100).

\subsection{Corinthians 12: $1-4$}

\subsubsection{Introduction}

Placed side by side, verses 2 and 3, 4 show the following similarities:

\section{L (verse 2)}

a. oîda ánthrōpon en Christō pró etōn dekatessárōn,

b. eíte en sõmati ouk ô̂da, eite ektòs toû sōmatos ouk oîda, ho thèos ồden,

c. harpagénta tòn toioûton héôs trítou ouranoû.

d. -

Verses 2-4 are constructed along parallel lines. In I and II the three members, namely the person (a), the participation of the body (b), and the rapture (c), are almost verbally identical. This parallelism, as well as the single time factor ('fourteen years ago', la) indicates that Paul is undoubtedly speaking of one experience only, not of two (Bachmann 1918: 394; Bultmann 1976: 223; Schäfer 1984: 22; Windisch 1924: 371).

In $\mathrm{Ib}$ and $\mathrm{IIb}$ the apostle shows acquaintance with two different forms of celestial journeys known in the ancient world, namely, soul-flight (i e ecstasy) and bodily rapture (Baird 1985: 654; Lietzmann 1969: 153f; Oepke 1935: 447-50; Windisch 1924: 374). Though Paul twice professes 
not to know whether the experience in (b) was 'in the body or out of the body', he plainly reckons with the possibility that even in the present life the ' $\mathrm{I}$ ' can separate from the physical body (Bultmann 1968: 203).

\subsubsection{Some points of exegesis}

3.2.2.1 In verse 1 Paul speaks of 'visions and revelations from the Lord' (NIV). The use of the plural and the absence of articles may indeed indicate only that the apostle is taking up a general topic, not that he has in mind numerous specific 'visions and revelations' (so eg Bultmann 1976: 220; Furnish 1984: 524). Some interpreters maintain that the terms optasiai ('visions') and apokalúpseis ('revelations') 'cannot be nicely distinguished' (Barrett 1976: 307; Bultmann 1976: 220) and that in this context, the terms may be regarded as synonymous (Furnish 1984: 524; Windisch 1924: 368). But this does not agree with the context. Plummer is right that it is perhaps true to say that, except in the Apocrypha, optasia 'always means a vision that reveals something' (1915: 338). If this is true, the difference is that in optasiai 'something is visually presented to the observer, while "revelations" are not always mediated through what can be seen' (Tasker 1958: 170; Jager sa: 227; Lenski 1937c: 1291).

3.2.2.2 Paul does not say whether on this occasion he saw the Lord or not. In fact, he does not say that he saw anything, but only that he heard (èkousen, IId) 'words that may not be said' (árrèta rhèmata) (v 5). However, to conclude from this that 2 Corinthians 12 'describes revelatory experiences through which nothing is communicated' (Baird 1985: 655; Schäfer 1984: 23) is going too far. Paul's silence on this point can be readily explained on other grounds (cf Hughes 1962: 428-429). It is probably not without reason that he subsumes this experience under the categories of both optasiai and apokalupseis; he did also see something although he does not refer to it. But it is the context rather than any specific term that suggests that the apostle's experience was more than only an auditory one. It is impossible to envisage the nature of a 'rapture' to 'paradise'/'the third heaven' if nothing was seen by Paul. In the light of apocalyptic literature,

In paradise, Paul should have viewed the final abode of the souls of the righteous (2 Esdr 8: 51-52; Luke 23: 43); and in the highest heaven, he should have seen cosmic paraphernalia, angelic beings, and the radiant throne of God (2 Enoch 20: 1-4; T.Levi 3: 1-8; 2 Apoc. Bar. 11: 1-9) (Baird 1985: 655 and n19). 
3.2.2.3 Paul was 'caught up' 'as far as (héōs) the third heaven' (Ic), and 'to (eis) paradise' (IIc). In the cosmological speculations of 'late-Judaism' there was no uniform view about the number of heavens (cf Lincoln 1981: 78). Commonest was the idea of seven heavens (eg TLevi 2: 7ff; AscenIs 6: 13; 7: 13; 2En 8-22) (Bruce 1971: 246; Strack-Billerbeck 1926; 531-533; Windisch 1924: 371-373). But there is no indication that Paul held similar views: It is by no means certain that he was familiar with all the cosmological speculations of 'late-Judaism' (Plummer 1915: 343). Further, he describes his own rapture 'as far as' the third heaven as something great and pre-eminent (Origen) which he could hardly do 'if there still remains four heavens beyond the one to which he was carried' (Hughes 1962: 433; Lincoln 1978: 212). In addition, Scripture nowhere so much as hints at the existence of seven heavens. The Old Testament speaks of 'the heaven of heavens' (Dt 10: 14; Neh 9: 6; Ps 68: 33; 148: 4) and the Rabbis had an interpretation which took 'the heaven and the heaven of heavens' in 1 Kings 8: 27 as a reference to three heavens (Strack \& Billerbeck 1926: 531). But there is no direct evidence that 'third heaven' was equivalent to the Old Testament 'heaven of heavens' (Lincoln 1981: 78). It is uncertain whether Paul considered 'the third heaven' as the highest one (Bruce 1971: 247; Grosheide 1959: 341). Further, the parallelism between members Ic and IIc is not necessarily proof that 'the third heaven' ( $v$ 2) and 'Paradise' (v 4) are identical (cf Plummer 1915: 345) and that 'third heaven' is a mere 'variant designation' for Paradise (contra Lincoln 1978: 213; Hodge 1963: 282; Tasker 1958: 171). Granted then that these expressions may refer to different places, Paul implies at least that Paradise is located in the third heaven (Bruce 1971: 247; Kennedy 1904; 306 n1; Mattill 1979: 33; Schäfer 1984: 22), as was also done in one strand of Jewish tradition (eg 2En 8: 1-4, 8; ApMos 37: 5; 3Bar 4: 8) (Bultmann 1976: 223; Lietzmann 1969: 154; Lincoln 1981: 79; Windisch 1924: 372). Locating Paradise in the seventh heaven is nowhere attested (J Dupont, cited in Bultmann 1976: 223). The impression conveyed by verses $1-4$ is that the apostle was caught up into a place where he experienced the very presence of the risen Christ in the 'third heaven'/'Paradise'.

It is probable that in Paul's perspective there are only three heavens, as Bengel suggested, namely the heaven of the clouds, the heaven of the sun and the stars, and the heaven in which God dwells (Grosheide 1959: 341; Hughes 1962: 433; Plummer 1915: 343). Calvin's view, accepted by many (eg Barrett 1973: 310; Lincoln 1981: 78; Pop 1962: 353f) that the number 'three' has a symbolic significance indicating what is highest 
and most complete, is doubtful. The idea of a place is evidently included (Hughes 1962: 434; Lincoln 1978: 212).

3.2.2.4 In 2 Cor 12: 4 Paradise refers to a presently existing locality, is similar to Paradise in Luke 23: 43 (Fensham 1962: 935; Grosheide 1959: 342; Hanson 1954: 54; Hodge 1963: 283; Lincoln 1978: 214) and indicates 'the place of the righteous departed' (Lincoln 1978: 214). The reference to the 'tree of life' ( $\operatorname{Rv} 2: 7)$ links the heavenly Paradise with the original Paradise which Adam lost through sin (as already in eg TDan 5: 12; 1 En 25: 4f) (Hughes 1962: 436; Lincoln 1981: 80). Through Christ's work of redemption the Paradise that will be revealed at the end ( $R v 2: 7 ;$ cf $22: 2$ ) is already present in the unseen world and can be experienced now as the place where the righteous dead live in communion with Christ in the intermediate state ( $\operatorname{Lk} 23: 43$; cf 2 Cor 5: 8; Phlp 1: 23).

'If our Lord descended to Hades,' says Hughes, 'it was to liberate the souls of the just who had been awaiting His triumph and thence to lead them to the heavenly Paradise won for them through His conquest on the Cross. It was there that the penitent thief was with him on the day of His death. It was there that Paul was transported in this rapture which he experienced. It is there that, after death, the souls of believers are with Christ even now (Phlp 1: 23), rejoicing in His presence' (Hughes 1962: 436; cf Fensham 1962: 935).

\subsubsection{Significance of the event}

It is difficult to determine the precise significance for our subject of Paul's rapture into Paradise. The fact that he relates an experience which occurred so long ago is indicative of the profound significance he attached to it. Two points seem obvious. First, through this rapture Paul became an 'eye-witness' to the condition of the righteous dead in the intermediate state. There is a general tendency to disregard or minimize the significance of this event in relation to Paul's teaching on the intermediate state. Many would agree with Kennedy that 'it is needless to expect any real light on St Paul's conception of the future condition of believers from the mysterious words of 2 Corintians xii. 1-4' (1904: $306 \mathrm{n} 1$ ). In part this is true. Paul admits that he 'heard inexpressible words which a man is not permitted to speak' ( $v 4 b)$. He was conscious of a divine restraint prohibiting him from revealing the mysteries of Paradise. Yet his own anticipatory experience of Paradise must necessarily have determined decisively his perspective on the condition of 
the faithful in the intermediate state (cf Lincoln 1978: 215). Second, a proper recognition of the eye-witness character of Paul's teaching on the intermediate state, may facilitate the interpretation of relevant key passages such as 2 Corinthians 5: 1 and following verses, Philippians 1: 23, the 'sleep' metaphor, et cetera. His implicit claim is throughout: 'I was there!' 'I had an optasia, an apokálupsis of Paradise' (vv 2, 4). Paul's own experience disproves decisively the doctrine of a psuchopannuchía. The 'sleep' of the righteous dead is plainly not a soul-sleep in the intermediate state. In addition, by recognizing the eye-witness character of Paul's teaching on the intermediate state, the supposed influences from other sources, whether Hellenistic or late-Judaistic, can be placed in the right perspective. Similarities of vocabulary as Trench pointed out (in a different connection), can now be recognized as they truly are, as instances where such words are assumed into the service of the Gospel making 'them vehicles of far higher truth than any which they knew at first, transforming, and transfiguring them . .' (1978: 102).

\subsection{Philippians 1: 23}

\subsubsection{Introduction}

Verses 21-24 which form part of a larger pericope (vv 12-26) are tied together 'around the alternating ideas already begun in $v 20$ of life and death whose differing expressions serve to support and explain each other' (Hawthorne 1983: 44). A number of striking parallels exist with 2 Corinthians 5: 1-10 (Hahnhart 1966: 180, 181). Here we merely draw attention to the correspondence between verse 23 and its closest parallel, 2 Corinthians 5: $8 \mathrm{~b}$ :

(a) 2 Corinthians 5: $8 \mathrm{~b}$

(i) ekdèmēsai ek toû sōmatos

(ii) kaí (explicative)

(iii) endēmèsai pròs tòn Kû̉rion (b) Philippians 1: 23b

(i) (eis) tō analüsai (cf kataluthe, 2 Cor 5: 1)

(ii) kai (explicative)

(iii) sùn Christō einai

The parallel references to the intermediate state in members (a) (iii) and (b) (iii) are especially noteworthy.

\subsubsection{Some points of exegesis}

Verse $23 \mathrm{f}$ is an elucidation of $\mathrm{v} 22 \mathrm{~b}$, kai ti $k t l$. Syntactically we have but one colon consisting of a Nominal Part (sc egō) and a Verbal Part (sunéchomai) which is greatly expanded. 
The verb sunéchomai, implying the pressure which confines and restricts' (Plummer sa: 29), describes the stress Paul felt with two equally strong desires pressing in on him from both sides (ek tōn dúo). These two desires are placed ' in a perfectly balanced construction cbscured by punctuation and by most, if not all, translations' (Hawthorne 1983: 48), namely

(a) tēn epithumian échōn eis

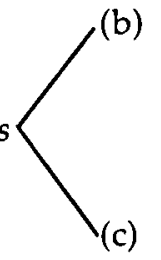

tò analûsai kaì sûn Christō eînai [tò] esti pollō gâr mâllon krềsson [di' eme]

dè

tò epiménein en tē sarkí [hò esti] anangkaiteron di' humâs

Our concern is with (b). The eis in (a) indicates the direction of his desire (Schenk 1984: 154). The kai in (b) is explicative (Gnilka 1980: 73). The two infinitives in (b) have only one article; the actions described by these infinitives are to be regarded as two aspects of the same thing, 'like two sides of the same coin' (Hoekema 1979: 104; Plummer sa: 30; Stauffer 1955: 212; cf Robertson 1934: 787).

Paul's 'desire' is eis tò analûsai. The aorist infinitive envisages the momentary experience of death as contrasted with the uninterrupted ('being' einai, praes infin) 'with Christ.' Some Bible translations render the infinitive by 'to depart' (cf AV, RV, ASV), or 'to be gone' (JB); others are more specific, 'to leave this world' (Barclay; Phillips). Some commentators take sárx in (c) in the generalized sense of '(sphere of) bodily or physical life' so that 'to abide in the flesh' means 'in (the sphere of) physical life' (Reicke 1965: 201), or 'in the solidarity of earthly existence' (Robinson 1952: 21). In the context, however, sárx does not refer to a ceparture from the world - however true this may be in itself. The tò analûsai $k t l$ in verse 23 has its counterpart in to epiménein ktl in verse 24 . The sár $x$ has the same meaning in verse 24 as sár $x$ in verse 22 , and sōma in verse 20 (Greijdanus 1937: 146; Lenski 1937 a: 747), namely sárx 'om het zwakke, broze aan te geven ...'(Greijdanus 1937: 141). 'Vlees', says Matter, 'is hier, evenals 2 Cor 4:10v identiek met "lichaam"' (Matter 1965:35). In verse 24 then the meaning of tē sarkí is 'het vleesch, d.i. mijn vleesch, d.i. lichamelijk blijven leven' (Greijdanus 1937: 146; Ewald 1917: 90), ie 'to stay alive in this body' (JB). This use of sárx = sōma is quite common elsewhere in Paul, for example in 2 Corinthians 12: 7, 
Galatians 4: 14, Ephesians 5: 29, 31 etc. Also in Greek literature we find 'dass schon früh auch der Terminus sárx für sōma eintreten kann' (Schweizer 1957: 238). The options before Paul are whether 'to stay on' in the sárx $(=$ sōma) or 'to depart' from the sárx (= sōma) and 'be with Christ' (De Vogel 1977: 271).

Metaphors picture realities. The word analúein is used in the LXX and in Hellenistic Greek as an euphemism for death (Lohmeyer 1964: 63; Moulton \& Milligan 1963: 36). The metaphor probably goes back to its military use for 'breaking' a camp, or even better, for 'striking' a tent (Lightfoot 1953: 93: Plummer sa: 30) rather than its nautical use (contra Beare 1969: 63). The former use falls in with 2 Corinthians 5: 1 (kataluthe - Vincent 1957b: 28).

Paul's use of analuein as departing from the body does not include the typical Greek view of death as a liberation of the immortal 'soul' from its prison-house, the mortal evil body. For (i) although in various texts apoluein and luein signify the return of the soul to the god(s), no example of any such use of analúein is known (Gnilka 1980: 73f). (ii) In the present passage as in 2 Corintians 5: 1 and following verses, Paul uses 'a quantity of Hellenistic language', eg kérdos (v 21); mâllon krê̂sson (v 24)) (Dupont cited in Gnilka 1980: 74f; Palmer 1975: 217). But, once again, he does not use such terms in their normal Hellenistic sense (Hoffmann 1969: 296).

Closest in wording to sùn Christō ê̂nai are sùn Kuriō esómetha (1 Th 4: 17), and sùn autō zēsomen (5: 10). In some five more passages the phrase 'with Christ' is linked with some other verb, namely 1 Thessalonians $4: 14 ; 2$ Corinthians $4: 14 ; 13: 4$; Romans $6: 8 ; 8: 32$. In all these passages the reference is to the Parousia. But in Philippians 1: 23 not the Parousia but the moment of death is in view.

It is uncertain whether Paul's phrase sun Christō einai links up, at least terminologically, with the Greek formula sùn theo (theoîs) (contra Grundmann 1964: 767, 5f). The latter formula referred exclusively to the assistance the god(s) rendered to men during their earthly life (Gnilka 1980: 89). The communion with the deity which the Greek hoped to attain after death, was not only described in a different way, but as a rule it concerned a plurality of gods (Grundmann 1964: 781, 7ff). For Paul, however, it involves personal communion with the risen and glorified Christ. Also the secular graffito which Deissmann considers a 'remarkable parallel to Phil.i.23' (Deissmann 1978: 301 n 1), namely eúchomai kagō en tachù sùn soì eînai, is no real parallel. The graffito did 
not envisage a reunion with the gods, but with some deceased person (Grundmann 1964: 781, 17f).

The sun with the dative in our present passage implies closer union than metá with the genitive (Greijdanus 1937: 144; Matter 1965: 33; Plummer sa: 33 ). Paul's meaning can only be properly explained in the light of the OT (cf the communion with God envisaged in the LXX version of certain Psalms, for example Psalms 139: 14 (sún); $20: 7$ (metá)) (Grundmann 1964: 781,4ff; contra Gnilka 1980: 89); the teaching of Jesus Himself (eg Mt 22: 31, 32; Lk 16: 19-31; 23: 43); and above all, probably, his personal experience as 'a man in Christ' who, a few years before, 'was caught up to the third heaven' and 'into Paradise' (2 Cor 12: 2, 4). The communion envisioned is a 'face to face converse with the Lord' (cf 2 Cor 5:8).

The question remains how Paul envisages the sùn Christō einai.

First, the phrase evidently includes something different from the communion which the believers may enjoy here and now through faith in Christ. The latter Paul already experienced (G1 2: 20); the former he would enjoy only after his 'departure'.

Second, the phrase does not refer to an experience peculiar to Paul the apostle and martyr. The belief 'einer besonderen himmlischen Auferstehung der Märtyrer' (Kellermann 1979: 109) developed in 'lateJudaism' (eg 2 Makk 7: 1ff; 14: 37ff; 15: 12ff) and was commonly held in the partristic period (Lohse 1963: 204ff; Stauffer 1955: 186). It is argued that it was taken over by the NT as well (Kellermann 1979: 109ff; Lohse 1963: 204). Lohmeyer gives a martyrological interpretation of the Letter to the Philippians as a whole (1964). For Paul, the martyr, 'to die is gain' (v 21) since 'ein besondere Art von Auferstehung' awaits him (Schweitzer 1954: 137); he would receive the 'crown' of martyrdom, that is the resurrection body, and sùn Christō einai, immediately on death (Kellermann 1979: 110ff; Lohmeyer 1964: 57ff; Matter 1965: 31f). We merely list our objections: (i) It is by no means certain that Paul did have a martyr-death in mind in Phillipians 1: 23 (Gnilka 1980: 75; Hunzinger cited in Kellermann 1979: $109 \mathrm{n}$ 58). (ii) The alleged points of correspondence with Jewish martyr-theology are misleading and inconclusive (cf Lincoln 1981: 104). (iii) In 2 Corinthians 5: 1ff Paul does not see the effects of his own death (kataluthenai) as different from that of all believers (cf hëmōn vv 1ff). (iv) Paul's hope is 'never based on the nature of his own death, but on the once-for-all death and resurrection of Christ ...' (Hahnhart 1966: 182; Gnilka 1980: 75). (v) Paul himself awaits 
the resurrection from the dead at the Parousia (3: 11, 20f) as an event separate from that of $1: 23 \mathrm{f}$.

Third, the phrase does not refer to a resurrection of the body immediately at the individual's death. For (i) Paul is not using resurrection language in Philippians 1:20,24. 'The resurrection is not before his mind at all in this passage' (Kennedy 1970: 429). (ii) Paul envisages an eschatological climax and a resurrection of all believers at the Parousía only (cf $1: 6,10 ; 2: 16 ; 3: 20,21$ ). (iii) In 2 Corinthians 5: 1ff Paul envisions a condition of disembodied existence in the very presence of Christ (vv 4,8) immediately after death.

Fourth, the phrase does not envisage a condition of soul-sleep. 'To be with Christ' is not simply one of more Biblical images describing the 'special nearness' to God, in the intermediate state, of persons who died as a whole, that is body and soul (contra Cullmann 1958: 51ff). For (i) the idea of an unconscious 'special nearness' to Christ of a wholly dead man-as-a-whole makes senseless both Paul's conviction that 'to die is gain' (v 21), and his desire to be with Christ 'because it is far better' (v 23). 'Denn die Sehnsucht nach dem Tode hat nur dann einen Sinn, wenn sie das sofortige Sein "bei Christus" begründet' (Meinertz 1950: 222). (ii) the thought of an unconscious state of soul-sleep is foreign to the context of the present passage as well as that of other related Pauline passages (eg 2 Cor 5: 1-10; 12: 1-4), and the teaching of Jesus (cf Mt 22: 32; Mk 5: 39 par; Lk 16: 19-31; 23: 43). The phrase to 'be with Christ' envisages an intimate conscious communion with Christ. (See discussion under next point.)

Fifth, the phrase describes the state and location of the blessed during the interim period between death and the Parousia. Dying ( $v 23$ ) is conceived as a change, a removal. The preposition sun conveys the notion of 'place' (cf Matter 1965: 33). The thought of a change of place (cf analúsai) in order to be with Christ in a disembodied form, and uninterruptedly until the Parousia (cf einai), is unmistakably included. But no closer identification is given of either location or state. The sun Christō eînai (23) recalls the endèmēsai pròs tòn Kúrion of 2 Corinthians 5:

8 . The communion envisaged will be an uninterrupted einai 'face to face converse with the Lord'. Hence to die is 'gain' (v 21). Yet the sùn Christō einai is not a final state and does not replace the expectation of the resurrection at the parousia (3: 20f).

Paul's view includes a conception of man as 'a duality of two parts, corporeal and incorporeal, meant to function in unity but distinguish- 
able and capable of separation' (Gundry 1976: 154), that is man as consisting of 'soul' and 'body'. For Paul the egō who desires 'to depart' and be 'with Christ' (v 23) and the hemeîs whose 'earthly tent-house' can be 'torn down' (2 Cor 5: 1) and who is 'in the tent' groaning and desiring 'not to be unclothed but clothed upon' (5: 4), is a 'conscious being' who can survive physical death (cf De Vogel 1977: 271; contra Matter 1965: 33f). Yet, his view is not Hellenistic but Hebraic (Stacey 1956: 126): (i) The anthropological duality (soul/body) was already something like 'the normative view' in 'late-Judaism' (cf 4Ezr 7: 78; ApMos 32: 4; WisSol 9: 15) (Gundry 1976: 87; De Vogel 1977: 264ff). (ii) Paul's personal experience of the glorified Christ (2 Cor 12: 1-4), and Christ's own teaching to His disciples (eg Lk 23: 43; etc) speak forcibly against assuming here Greek speculations on a soul-flight to celestial regions after death. The apostle's view is wholly Christologically determined (Lightfoot 1975: 92).

\subsection{Thessalonians 4: 13}

\subsubsection{Summary of use of the term 'sleep' for death}

The use of 'sleep' as euphemism for death goes back as far as Homer, Iliad, XI, 241 (koimésato). The term appears very frequently in the Old Testament (where the LXX usually translates it by koimâsthai (cf Hatch \& Redpath 1954: 773f; Kennedy 1904: 267; Strack \& Billerbeck 1926, 634), in 'late-Judaism' (eg Jub 23: 1; 36: 18; 45: 15; AsMos 1: 15; 10: 15; ApBar 11: 4f; 85: 3), and in Rabbinic literature (Volz 1934: 257f, Whiteley 1974: 264f).

In the New Testament two verbs are used to describe death in terms of 'sleep', namely katheúdein and koimâsthai. (a) The word katheúdein appears twenty-two times, mostly in the Synoptic Gospels (fourteen), and almost exclusively to describe natural sleep. It refers to death in Mark 5: 39 (par in Mt 9: 24; Lk 8: 52), and 1 Thessalonians 5: 10 where katheúdōmen = apothnēskōmen ( $\mathrm{Rm} 14: 8)$ (Frame 1912: 189f). (b) The term koimâsthai, 'to fall asleep', appears eighteen times. (i) In fourteen of these instances it is used figuratively for death. It occurs very seldom in the gospels: only in Matthew 27: 52 and John 11: 11. In Paul it appears nine times, but only in two of his earlier letters: three times in 1 Thessalonians $(4: 13,14,15)$; six times in 1 Corinthians $(7: 39 ; 11: 30 ; 15$ : $6,18,20,51)$. (ii) In the metaphorical sense for death, koimâsthai appears twice in the present tense (1 Cor 11: $30,1 \mathrm{Th} 4: 13$ ); once in the future (1 Cor 15: 51), eight times in the aorist (Ac 7: 60; 13: 36; 1 Cor 7: 
39; 15: 6, 18; 1 Th 4: 14, 15; 2 Pt 3:4), and the three times in the perfect tense (Mt 27: 52; Jn 11: 11; 1 Cor 15: 20). Frame remarks that the present is either timeless indicating a class, "the sleepers," or it designates the act of sleep as in progress (cf 1 Cor 11: 30); the aorist views the act of sleep as entered upon in the past, without reference to its progress or completion; the perfect regards the act as completed in the past with the added notion of the existing state' (Frame 1970: 167; cf Bruce 1982: 98; Wohlenberg 1909: 98). (iii) The term can be used to describe the 'Vorgang des Sterbens (Ac 7: 60; 13: 36; 1 Cor 7: 39; 11: 30; 15: 6, 51; 2 Pt 3: 4)' as well as the 'Zustand des Todes (Mt 27: 52; 1 Kor 15: 18,20; 1 Th 4: 13, 14, 15)' (Völkel 1981: 746). It is used almost exclusively of dead 'Christians', for example of saints who departed before Christ came (Mt 27: 52; Ac 13: 36); of Lazarus who died while Christ was on earth (Jn 11: 11); and of believers since the resurrection of Christ (Ac 7: 60; 1 Cor 11: 30; 15: 6, 18, 51; 1 Th 4: 13, 14, 15). Two instances need not necessarily refer to believers (1 Cor 7: 39; 2 Pt 3: 4) (iv) Paul never uses the term 'sleep' of Christ's death; he uses apothaneîn. But Christ is designated as the aparchē tōn kekoimēménōn (1 Cor 15: 20). Conversely, Paul never uses the verb apothanein of the death of believers (cf Rm 8: 38 sic!); he uses koimâsthai (cf Wohlenberg 1909: $99 \mathrm{n7}$ ).

\subsubsection{The meaning of 'sleep' in Paul}

Jesus' words 'The child has not died, but is asleep' (katheúdei) (Mk 5: 39 NAS) have led some commentators to dispute that a real death was involved (Robinson 1928: 82); the girl could have been in a coma only (McNeile 1915: 126; Taylor 1952: 295). But most scholars agree that a genuine death occurred (so Klostermann 1971: 53; Lohmeyer 1963: 106f; Swete 1909: 108). Luke describes the miracle by adding that on Jesus' word 'child, arise!' (v 54) 'her spirit (to pneûma) returned' (v 55a). He thus envisions the girl's pnêิma as having been separated from her body, yet surviving death (cf Lk 23: 43, 46; Ac 7: 59) (Marshall 1978: 348), so that Jesus could call it back 'from the invisible realm' (Geldenhuys 1951: 262). Here pneûma is not equivalent to 'breath or life-principle' that is psuche (contra Ellis 1974: 130), but it is conceived of 'als den Tod überlebender Teil des Menschen' (Schweizer 1959: 413, 2f), a thought that was common in 'late-Judaism' (eg Jub 23: 26ff; 1 En 22; 39: 4ff) (Sjöberg 1959: 377, 27ff). This use of pneûma corresponds to that of psuche $\bar{e}$ in Greek thought (cf Stacey 1956: 126f), but Luke's usage goes back to the Old Testament (cf 1 Ki 17: 21) (Marshall 1978: 348). The girl's 
resurrection from the dead is a sign of the presence of the Kingdom of God (Bailey 1964: 163f). It is evident that no idea of a psuchopannuchia is in view. Jesus' use of 'sleep' here is in full harmony with His teaching elsewhere (eg Mt 22: 32; Lk 16: 19-31; Lk 23: 43 cf 46).

Seven of the Pauline uses of koimâsthai appears in a resurrection/ Parousía context (viz 1 Cor 15: 6, 18, 20, 51; 1 Th 4: 13, 14, 15). But the two contexts are not the same. Some among the Corinthians denied the resurrection itself (1 Cor 15: 12). The Thessalonians, however, did not question the fact of the resurrection. Their worry was over 'the status of dead Christians over against living ones at the Parousia ...' (Moore 1969: 67). Consequently, in replying to them, Paul's whole emphasis is on the fate of 'the dead in Christ' (v 16) in relation to the Parousia.

Cullmann concludes from 1 Thessalonians 4: 13 and following verses that the dead in Christ 'are still in time' and 'waiting' for the resurrection(1958: 49f). He argues that in the New Testament, 'sleep' signifies more than the mere "impression" of a peaceful going to sleep'; it refers to 'the condition of the dead before the Parousia' (p $5 \mathrm{n} \mathrm{6}$, italic Cullmann's). Or again, the 'expression to sleep which is the customary designation in the New Testament of the "interim condition", draws us to the view that for the dead another time-consciousness exists, that of "those who sleep"' ( $p$ 57). So for Paul the metaphor expresses a state of imperfection, that is a waiting for the resurrection ( $p 50$ ), the notion of 'special proximity to Christ' ( $p$ 52) and the temporal sense of the intermediate state (p 51, 52, 57).

Paul uses koimâsthai twice in the present tense, namely in 1 Thessalonians 4: 13 and 1 Corinthians 11: 30 . Bailey thinks that only in 1 Thessalonians 4: 13 where the present tense appears, 'do we find the term in a sense which would clearly indicate the state of the dead in their interim condition' (1964: 164). This is possible. The present tense may indeed refer to the 'continued state of being unconscious' (Whiteley 1974: 268; Frame 1970: 167). But the iterative sense is probably more correct. Grosheide takes the present tense in 1 Corinthians 11: 30 as implying that 'there are constantly some that die' (1953: 275f). The present tense in 1 Thessalonians 4: 13 may be understood in the same way (Morris 1956: 84; Robertson 1931: 31). Thus Cullmann's argument, based on the use of the present tense of the verb, is not very strong (Whiteley 1974: 269).

All special doctrinal inferences from Paul's use of koimâsthai are 'extremely precarious, especially those that favour the idea of a psuchopannuchia in the interim state ...' (Ellicott 1880: 61; Milligan 1908: 
56). For, (i) the metaphor simply goes back to the obvious analogy between the conditions of sleep and death (Alford 1958b: 272). It did not arise from the resurrection hope and should not be identified with the resurrection (Charles 1913: $127 \mathrm{n} 1$ ). It is found in cultures which held no belief in any kind of afterlife (Best 1972: 185). In itself the verb 'bezeichnet einfach den Todeszustand' (Von Dobschütz 1974: 187) and the meaning of a condition out of which one may be 'awakened' at the Parousía, is not implicit in the terms itself (Best 1972: 185; Marshall 1983: 119). Where the context demanded it, the term could be extended to take account of a belief in resurrection, as in the Old Testament (Dn 12: 2; cf Is 26: 19), in 'late-Judaism' (eg 2 Mac 12: 45; 4 Ezr 7: 32; 1 En 100: 5), and in the New Testament (eg Mt 27: 52; Mk 5: 39 par [katheúdō]; Jn 11: 11). But despite Paul's almost exclusive usage of the term in a resurrection/ Parousia context, the underlying metaphor must in no case be pressed as if descriptive of his idea of the intermediate state (cf Milligan 1908: 56). (ii) In Paul the term appears almost (if not altogether) exclusively in connection with 'Christian' dead. This implies that for 'those who have fallen asleep in Jesus' ( $v v 14,15$ ) the whole concept of death has been transformed: they no longer share the hopelessness of the pagan conception about the afterlife (cf Hendriksen 1955: 110f; Milligan 1908: 56). The constant resurrection/Parousia context in which 'sleep' occurs in Paul, indicates that the 'sleep' is to be understood in relation to the resurrection of the body. For the 'dead in Christ' (v 16), then, 'sleep' includes besides the idea of rest from labour also, and in particular, ideas of continued existence and of death as a state 'from which one would awake to resurrection life' (Bruce 1982: 96; Hendriksen 1955: 109; Morris 1956: 84). This note of hope, however, is not inherent of the term itself. It is arrived at 'by contextual inference and interpretation' (Bailey 1964: 166). (iii) The idea of a soul-sleep in the intermediate state is altogether foreign to Paul's conception of the condition of the dead in the period between death and resurrection. 'To be absent from the body' is equivalent to the endèmésai pròs tòn Kúrion (2 Cor $5: 8$ ) and the sún Christō einai (Phlp 1:23). These passages envisage a state of being in the presence of the Lord and experiencing an intimate and fully conscious interpersonal communion with Him immediately after death. Also the apostle's own experience described in 2 Corinthians 12: 2-4, discountenances any thought of a soul-sleep after death.

Our conclusion must be that Paul's use of the term 'sleep', as in the rest of the New Testament, is nowhere descriptive of the condition of the soul between death and Parousia. The 'sleep' applies only to the 
body of the dead believer, not to his soul (Lenski 1937b: 326; Hogg and Vine 1929: 128). This is evident from the fact that 'in the New Testament the resurrection is used of the body alone' (Hogg and Vine 1929: 128). When 'our earthly tent-house' is dismantled (2 Cor 5: 1) the disembodied spirit, the seat of personality (cf Ec 12: 7; Lk 23: 43,46) departs to be 'with Christ' (2 Cor 5: 8; Phlp 1: 23), which is 'very far better' than anything that we can experience 'while we are in this tent' (2 Cor 5: 4).

\subsection{Other relevant Pauline passages}

A few other passages in Paul may also have bearing on the interim period. Romans 8: 38 and 39 states in a quite general way the apostle's confidence that the 'sword' ( $v$ 35), and 'death' itself ( $v$ 38) cannot destroy the believer's (cf 'we', vv 35-9) intimate connection with Christ. There is a clear allusion to an unbroken communion with Christ even beyond death. The 'love of God', which is in Christ Jesus our Lord (v 39, cf 'the love of Christ', v 35) is recognized as the ground of this confidence in the face of (violent) death. There is no light here on the question how the love of God in Christ will be manifested beyond death to those who suffered even unto death for the sake of Christ.

The interpretation of 1 Corinthians 15: 29 is very uncertain and should not be included in a discussion of the intermediate state in Paul.

\section{CONCLUSION}

4.1 Paul's conception of the intermediate state cannot be explained adequately on the basis of a supposed development in his eschatological thinking. Attempts to prove that his eschatology underwent a significant change between 1 and 2 Corinthians (eg Bultmann 1968: 201f; Charles 1913: 437ff; Davies 1948: 311; Knox 1939: 128, 136) arouse scepticism on various scores (cf Berry 1961: $60 \mathrm{ff}$; Harris 1971: 32f; Lowe 1941: 129ff). Many remarkable parallels have indeed been identified between Paul's terminology and conceptions and those found in Hellenistic religious-philosophical thinking and in 'late-Judaism'. However, the following points should receive due consideration in any attempt to explain such parallels.

First, Paul's views on the intermediate state stand wholly within the tradition of the Urgemeinde (cf Ladd 1974: 391ff; Machen 1925: 144ff). In all essential points Paul's teachings correspond with that of Jesus. The following parallels illustrate the point: 
Jesus

(a) The resurrection from the dead is a still future event (Mt 22: 29-32; Lk 23: 43 [Paradise!]).

(b) The righteous dead are alive beyond the grave (Mt 22: 32; Lk 16: 9, 22-30; 23: 43).

(c) The righteous dead are 'with Christ' and 'in Paradise' (Lk 23: 43).

(d) The figure of 'sleep' can only refer to the body (Mk 5: 39 par; as compared with $\operatorname{Lk}$ 16: 9, 22-30; 23: 43).

(e) Jesus 'supposes' a body/soul duality in man (Mk 5: 39 par; Lk 12: $20 ; 16: 9,22-30 ; 23: 43$; cf Jn 11: 11-14, 43, 44).

(f) The intermediate state is 'very far better' than 'to remain in the flesh' (Lk 16: 25; 23: 43).

(g) Christ was in Paradise (Lk 23: 43).

(h) Jesus sheds more light on the interim state than Paul (Lk 16: 22-30).
Paul

(a) The resurrection from the dead is a still future event ( 2 Cor 5 : 1-10; Phlp 1: 23; 1 Th 4: 13, 14; Rm 8: 38f; as compared with eg 1 Cor 15; Phlp 3: 20, 21; 1 Th 4: 15-18).

(b) The righteous dead are alive beyond the grave (2 Cor 5: 1,2 , 4, 6-8; Phlp 1: 23 of 3: 20, 21; Rm 8: 38f).

(c) The righteous dead are 'with Christ' (2 Cor 5: 8; Phlp 1: 23), and in 'Paradise' (cf 2 Cor 12: 4)

(d) The figure of 'sleep' can only refer to the body (1 Th $4: 13-16$ as compared with 2 Cor 5: 1-10; Phlp 1: 23).

(e) Paul 'supposes' a body/soul duality in man (2 Cor 5: $1-10$; 12: 2-4; Phlp 1: $23 ; 1$ Th 4: 13, 14).

(f) The intermediate state is 'very far better' than 'to remain in the flesh' (2 Cor 5: 8; Phlp 1: 23).

(g) Paul was raptured to Paradise (2 Cor 12: 4).

(h) Paul is not permitted to speak on what he 'heard' in Paradise (2 Cor 12: 4).

In fact there is not a single point on which Paul deviates from Jesus' teaching. This close correspondence indicates that Paul must have been intimately acquainted with the teaching of Jesus and that his own understanding of the intermediate state must have been moulded by the 'word of the Lord' (cf Pinnock 1965: 12).

Second, Paul claims that God's secret purpose musterion which has been revealed to him concerns among other things the Parousia (1 Cor 
15: 51) as well as the relation to the Parousia (1 Th 4: 13-16) of those who died before the Parousia that is those who are now living in the interim state. It is within this context that 2 Corinthians 12: 1-4 assumes special significance. Through his rapture to Paradise (v 4) Paul evidently received first-hand insight into the 'mystery' of the fate of the 'dead in Christ' in the interim period. When writing about (eg 2 Cor 5: 1-10), or alluding to (eg Phlp 1: 23; Rm 8: 35, 38f; 1 Th 4: 13-15) the interim period, Paul could say, as it were, 'I have been there!' 'I had an optasía, an apokálupsis, of Paradise' (2 Cor 12: 2,4). For although Paul was modest and reticent about his experience in Paradise, the event had a decisive influence on his ministry. The 'thorn in the flesh' $(v 7 c)$ that was given him, would not only keep him from exalting himself (v 7b), or keep reminding him of the all-sufficient grace of Christ (v 9), but it would, too, remind him constantly of his rapture to Paradise 'fourteen years ago' (v 2) and his experience there (v 4).

In becoming 'all things to all men' ( $\operatorname{cf} 1$ Cor 9: 22) Paul would assume into the service of the Gospel many current terms and expressions which would be associated in Hellenistic usage with different religiousphilosophical conceptions. It is altogether improbable in the light of the decisive influence of Jesus' own teaching in the tradition of the Urgemeinde and Paul's own experience described in 2 Corinthians 12: 1-4 that he would have taken over also the pagan religious conceptions associated with such terms. Rather, such terms would become 'vehicles of far higher truth than any they knew at first, transferring and transforming them ...' (Trench 1978: 102; cf Deissmann 1978: 265, 351), that is such terms would, as it were, be wholly Christianised.

4.2 In Paul's perspective only the bodies of 'those who have fallen asleep in Jesus' (1 Th 4: 14) are 'asleep' in the interim period. Assuming the same body/soul duality as Jesus, the apostle speaks about the disembodied existence of believers after death in a manner that shows various close verbal parallels with contemporary Hellenistic and 'lateJudaistic' views. For Paul, however, the whole concept of life in the intermediate state centres in Christ. 'To depart' from the body means that the disembodied soul immediately is 'at home with the Lord' (2 Cor 5: 6, 8; Phlp 1: 23). And although such disembodied existence is in itself not as excellent as the resurrection life (cf 1 Cor 15: 50-57; 2 Cor 5: 1-9), yet, to 'be with Christ' in the interim period is 'very far better' (Phlp 1: 23; cf 2 Cor 5: 4) than 'to live on in the flesh' (Phlp 1: 22). Thus to 'die' is in fact, 'gain' (v 21). 
To 'be at home with the Lord' (2 Cor 5: 8) and to 'be with Christ' (Phlp 1: 23) - Paul does not go further than this. He is not permitted to reveal the secrets of Paradise. It is enough for the believer to know that even death cannot separate 'us' from the 'love of God in Jesus Christ' (Rm 8: 38).

\section{Works consulted}

ALDERINK, LJ 1981. Creation and salvation in ancient Orphism. Chico: Scholars Press.

ALFORD, H [1849] 1958a. The Greek Testament. Vol 1, The four Gospels. Revd by EF Harrison. Reprint. Chicago: Moody.

ALFORD, H [1856] 1958b. The Greek Testament. Vol 3, Galatians-Philemon. Revd by EF Harrison. Reprint. Chicago: Moody.

BACHMANN, P 1918. Der Zweite Brief des Paulus an die Korinther. 3. Durchgesehene Aufl. Leipzig: Deichert. (KNT 8.)

BAILEY, RE 1964. Is "sleep" the proper Biblical term for the intermediate state? ZNW 55, $161-167$.

BAIRD, W 1971. The Gospel according to Luke, in Layman, CM (ed), The interpreter's one-volume commentary on the Bible, 672-706. Nashville: Abingdon.

BAIRD, W 1985. Visions, revelation, and ministry: Reflections on 2 Cor 12: 1-5 and Gal 1: 11-17. JBL 104, 651-662.

BARRETT, CK 1973. A commentary on the second epistle to the Corinthians. London: A \& C Black. (BNTC.)

BEARE, FW 1969. The epistle to the Philippians. 2nd ed. London: Black. (BNTC.)

BERNARD, JH [sa] 1970. The second epistle to the Corinthians, in Nicoll, WR (ed), The expositor's Greek Testament, Vol 3, 1-119. Reprint. Grand Repids: Eerdmans.

BERRY, R 1961. Death and life in Christ. The meaning of 2 Corinthians 5. 1-10. SJTh 14, $60-76$.

BEST, E 1972. A commentary on the first and second epistles to the Thessalonians. London: A \& C Black. (BNTC.)

BIETENHARD, H 1969. sv 'Paradies' TBLNT II/I, 997-998.

BLASS F, DEBRUNNER A \& REHKOPF F 1976. Grammatik des neutestamentliche Griechisch. 14. völlig neuarbeitete und erweiterte Aufl. bearb. Von F Rehkopf. Göttingen: Vandenhoeck.

BORSE, U 1972. Zur Todes- und Jenseitserwartung Pauli nach 2 Kor 5, 1-10. BiLe 13, $129-138$.

BRUCE, AB [sa] 1970. The synoptic gospels, in Nicoll, WR (ed), The expositor's Greek Testament, Vol 1,1-651. Reprint. Grand Rapids: Eerdmans.

BRUCE, FF 1971. 1 and 2 Corinthians. London: Oliphants. (NCeB.)

BRUCE, FF 1982. 1 and 2 Thessalonians. Waco: Word Books (WBS 45.)

BRUN, L 1929. Zur Auslegung von II Cor 5: 1-10. ZNW 28, 207-229.

BULTMANN, R [1947] 1963. Exegetische Probleme des zweiten Korintherbriefes. 2. Aufl. Darmstadt: Wissenschaffliche Buchgesellschaft.

BULTMANN, R 1968. Theologie des Neuen Testaments. 6. Aufl. Tübingen: Mohr.

BULTMANN, R 1976. Der zweite Brief an die Korinther, hrsg von E Dinkler. Göttingen: Vandenhoeck. (KEK 6.)

CASSIDY, R 1971. Paul's attitude to death in II Corinthians 5: 1-10. EQ 43, 210-217.

CHARLES, RH 1913. A critical history of the doctrine of a future life in Israel, in Judaism, and in Christianity. 2nd ed. London: A \& C Black.

COLE, A 1961. The Gospel according to St Mark. London: Tyndale (TNTC.)

CRANFORD, L 1976. A new look at 2 Corinthians 5: 1-10. SWJT 19, 95-100. 
CREMER, H 1895. Biblico-theological lexicon of New Testament Greek. 4th ed. Edinburgh: Clark.

CULLMANN, O 1958. Immortality of the soul or resurrection of the dead? The witness of the New Testament. London: Epworth.

CUMONT, F 1922. After life in Roman paganism. New York: Dover.

CUMONT, F 1949. Lux Perpetua. Paris: Geuthner.

DAVIES, WD 1948. Paul and Rabbinic Judaism. Some Rabbinic elements in Paul. London: SPCK.

DEISSMANN, A [1908] 1978. Light from the ancient east. The New Testament illustrated by recently discovered text of the Graeco-Roman world. Tr by LRM Strachan. Grand Rapids: Baker.

DE VOGEL, C J 1977. Reflexions on Philipp. I 23-24. NT 19, 262-74.

ELLICOTT, CJ 1880. St Paul's epistles to the Thessalonians. 4th ed. London: Longman.

ELLIS, EE 1960. II Corinthians V. 1-10 in Pauline eschatology. NTS 6, 211-224.

ELLIS, EE 1974. The Gospel of Luke. Rev ed. London: Oliphants.

EWALD, P 1917. Der Brief des Paulus an die Philipper. 3. durchgesehene und vermehrte Aufl. besorgt von G Wohlenberg. Leipzig: Deichert. (KNT 11.)

FENSHAM, FC 1962. sv 'Paradise'. NBDict.

FRAME, JE 1912. A critical and exegetical commentary on the epistles of St Paul to the Thessalonians. Edinburgh: Clark. (ICC.)

FURNISH, VP 1984. II Corinthians. New York: Doubleday. (AncB 32A.)

GELDENHUYS, N 1951. Commentary on the Gospel of Luke. Grand Rapids: Eerdmans. (NIC.)

GLASSON, TF 1961. Greek influence in Jewish eschatology. With special reference to the Apocalypses and pseudepigraphs. London: SPCK.

GNILKA, J 1980. Der Philipperbrief. 3. Aufl. Freiburg: Herder. (HThK 10/3.)

GODET, F [1870] sa. A commentary on the Gospel of St. Luke. 2 vols. 5th ed. Tr by EW Shalders. Edinburgh: Clark.

GREIJDANUS, S 1937. De brief van den apostel Paulus aan de gemeente te Philippi. Amsterdam: Van Bottenburg. (KNT 9/2.)

GREIJDANUS, S 1941. Het heilige evangelie naar de beschrijving van Lucas. Bd 2. Amsterdam: Van Bottenburg. (KNT 3/2.)

GROSHEIDE, FW 1922. Het heilige evangelie volgens Mattheüs. Amsterdam: Van Bottenburg. (KNT 1.)

GROSHEIDE, FW 1953. Commentary on the first epistle to the Corinthians. Grand Rapids: Eerdmans. (NIC.)

GROSHEIDE, FW 1959. De tweede brief aan de kerk te Korinthe. 2de, herziende druk. Kampen: Kok (CNT (K).)

GRUNDMANN, W 1935. sv dēmos, ktl. ThWNT II, 62-64.

GRUNDMANN, W 1964. sv sún-metá, $k t l$. ThWNT VII, 766-798.

GRUNDMANN, W 1972. Das Evangelium nach Matthäus. 3. Aufl. Berlin: Evangelische Verlagsanstalt. (ThHK 1.)

GRUNDMANN, W 1973. Das Evangelium nach Markus. 6. Aufl. Berlin: Evangelische Verlagsanstalt. (ThHK 2.)

Gundry, RH 1976. Sōma in Biblical theology. With emphasis on Pauline anthropology. Cambridge: University Press. (MSSNTS 29.)

GUTHRIE, WKC 1950. The Greeks and their gods. Boston: Beacon.

GUTHRIE, WKC 1966. Orpheus and Greek religion. A study of the Orphic movement. New York: Norton.

HAHNHART, $\mathrm{H}$ 1966. The intermediate state in the New Testament. DD thesis, University of Amsterdam. Groningen: VRB.

HANSON, RPC 1954. The second epistle to the Corinthians. Christ and controversy. London: SCM (TBC.) 
HARRIS, MJ 1971. 2 Corinthians 5: 1-10: Watershed in Paul's eschatology? TynB 22, 32-57.

HARRIS MJ 1974. Paul's view of death in 2 Corinthians 5: 1-10, in Longenecker, RN \& Tenney, MC (ed), New dimensions in New Testament Study, 317-328. Grand Rapids: Zondervan.

HATCH, E \& REDPATH, HA [1897] 1954. A concordance to the Septuagint and the other Greek versions of the Old Testament (including the apocryphal books). 2 vols. Reprint. Graz: Akademische Druck- u. Verlagsanstalt.

HAWTHORNE, GF 1983. Philippians. Waco: Word Books. (WBC 43.)

HENDRIKSEN, W 1955. Exposition of I and II Thessalonians. Grand Rapids: Baker.

HETTLINGER, RF 1957. 2 Corinthians 5.1-10. SITh 10, 174-194.

HILL, D 1972. The Gospel of Matthew. London: Oliphants (NCeB.)

HODGE, C [1869] 1963. A commentary on the second epistle to the Corinthians. Reprint. London: Banner of Truth.

HOEKEMA, A 1979. The Bible and the future. Grand Rapids: Eerdmans.

HOFFMANN, P 1969. Die Toten in Christus. Eine religionsgeschichtliche und exegetische Untersuchung zur paulinischen Eschatologie. 2. Aufl. Münster: Aschendorff. (NTA NF 2.)

HOGG, CF \& VINE, WE 1929. The epistles to the Thessalonians. Rev ed. Grand Rapids: Kregel.

HUGHES, PE 1962. Paul's second epistle to the Corinthians. Grand Rapids: Eerdmans. (NIC.) JAGER, HJ sa. De tweede brief aan de Korinthiers. Kampen: Copiëerinrichting vd Berg.

JEREMIAS, J 1933a. sv Hadès.ThWNT I, 146-150.

JEREMIAS, J 1933b. sv anthrōpos, $k t l$. ThWNT I, 365-367.

JEREMIAS, J 1933c. sv géenna. ThWNT, 655-656.

JEREMIAS, J 1954. sv parádeisos. ThWNT V, 763-771.

JEWETT, R 1971. Paul's anthropological terms. A study of their use in conflict settings. Leiden: Brill.

KELLERMANN, U 1979. Auferstanden in den Himmel. 2 Makkabäer 7 und die Auferstehung der Märtyrer. Stuttgart: KBW. (SBS 95.)

KENNEDY, HAA 1904. St Paul's conceptions of the last things. 2nd ed. London: Hodder \& Stoughton.

KENNEDY, HAA [sa] 1970. The epistle to the Philippians, in Nicoll, WR (ed), The expositor's Greek Testament, Vol 3, 397-473. Reprint. Grand Rapids: Eerdmans.

Klostermann, E 1971. Das Markusevangelium. Tübingen: Mohr. (HNT 3.)

KNOX, WL 1939. St Paul and the church of the gentiles. Cambridge: University Press.

KÜHNER, R \& GERTH, B [1904] 1963. Ausführliche Grammatik der griechischen Sprache. 2. Teil. Satzlehre. 3. Aufl. Hannover: Hahn:

LADD, GE 1974. A theology of the New Testament. Grand Rapids: Eerdmans.

LANG, FG 1973. 2 Korinther 5, 1-10 in der neueren Forschung. Tübingen: Mohr.

LENSKI, RCH 1937a. The interpretation of St Paul's epistles to the Galatians, to the Ephesians and to the Philippians. Minneapolis: Augsburg.

LENSKI, RCH 1937b. The interpretation of St Paul's epistles to the Colossians, to the Thessalonians, to Timothy, to Titus and to Philemon. Minneapolis: Augsburg.

LENSKI, RCH 1937c. The interpretation of St Paul's first and second epistles to the Corinthians. Minneapolis: Augsburg.

LIDDLE, HG \& SCOTT, R (comps) 1968. A Greek-English lexicon. Rev ed. Oxford: Clarendon.

LIETZMANN, H 1969. An die Korinther 1. Il. Ergänzt von Kümmel, WG. 5. Aufl. Tübingen: Mohr. (HNT 9.)

LIGHTFOOT, JB [1868] 1953. St Paul's epistle to the Philippians. Reprint. Grand Rapids: Zondervan.

LINCOLN, AT 1978. 'Paul the visionary': The setting and significance of the rapture to Paradise in II Corinthians XII. 1-10. NTS 25, 204-220. 
LINCOLN, AT 1981. Paradise now and not yet. Studies in the role of the heavenly dimension in Paul's thought with special reference to his eschatology. Cambridge: University Press. (MSSNTS 43.)

LOHMEYER, E 1963. Das Evangelium des Markus. 16. Aufl. Göttingen; Vandenhoeck. (KEK $1 / 2$.)

LOHMEYER, E 1964. Der Brief an die Philliper. 13. Aufl. Göttingen: Vandenhoeck. (KEK 9/1.)

LOHSE, E 1963. Märtyrer und Gottesknecht. Untersuchungen zur urchristlichen verkündigung vom Sühntod Jesu Christi. 2. Durchgesehene und erweiterte Aufl. Göttingen: Vandenhoeck.

LOWE, J 1941. An examination of attempts to detect developments in St Paul's theology. JThS 42, 129-42.

MACHEN, JG 1925. The origin of Paul's religion. Grand Rapids: Eerdmans.

MANSON, TW 1949. The sayings of Jesus. As recorded in the Gospels according to St Matthew and $S t$ Luke arranged with introduction and commentary. London: SCM.

MARSHALL, IH 1978. The Gospel of Luke. Exeter: Paternoster. (NIGTC.)

MARSHALL, IH 1983. 1 and 2 Thessalonians. Grand Rapids: Eerdmans. (NCeB.)

MATTER, HM 1965. De brief aan de Philippenzen en de brief aan Philemon. Kampen: Kok. (CNT(K).)

MATTILL, AJ 1979. Luke and the last things: A perspective for the understanding of Lucan thought. Dillsboro: Western North Carolina Press.

MCNEILE, AH 1915. The Gospel according to St. Matthew. London: Macmillan.

MEINERTZ, M 1950. Theologie des Neuen Testaments. 2. Bd. Bonn: Peter Hanstein.

METZGER, BM 1971. A textual commentary on the Greek New Testament. London: United Bible Societies.

MEYER, R 1938. sv kólpos. ThWNT III, 824-826.

MILLIGAN, G 1908. St Paul's epistles to the Thessalonians. London: Macmillan.

MOORE, AL 1969. 1 and 2 Thessalonians. London: Nelson.

MORRIS, L 1956. The epistles of Paul to the Thessalonians. London: Tyndale. (TNTC.)

MORRIS, L 1974. The gospel according to St Luke. London: IVP.

MOULE, CFD 1959. An idiom book of New Testament Greek. 2nd ed. Cambridge: CUP.

MOULTON, JH 1908. A grammar of New Testament Greek. Vol 1, Prolegomena. 3rd ed. Edinburgh: Clark.

MOULTON, JH \& Howard, WF [1929] 1968. A grammar of New Testament Greek. Vol 2, Accidence and word-formation. Edinburgh: Clark.

MOULTON, JH \& MILLIGAN, G [1914-30] 1930. The vocabulary of the New Testament illustrated from the papyri and other non-literary sources. London: Hodder \& Stoughton.

MUNDLE, W 1927. Das Problem des Zwischenzustandes in dem Abschnitt 2. Kor 5: 1-10, in Festschrift für Adolf Jülicher, 93-109. Tübingen: Mohr.

NILSSON, MP 1949. A history of Greek religion, tr by FJ Fielden. 2nd ed. Oxford: Clarendon.

ODEBERG, H 1938. sv Jakōb. ThWNT III, 191-192.

OEPKE, A 1933. sv gumnōs, ktl. ThWNT I, 773-775.

OEPKE, A 1935. sv ekstasis, existèmi. ThWNT II, 447-457.

PALMER, DW 1975. 'To die is gain' (Philippians i 21). NT 17,203-218.

PINNOCK, CH 1965. The structure of Pauline eschatology. EQ 37, 9-20.

PLUMMER, A sa. A commentary on St Paul's epistle to the Philippians. Reprint. Old Tappen: Revell.

PLUMMER, A 1915. A critical and exegetical commentary on the second epistle of St Paul to the Corinthians. Edinburgh: Clark. (ICC.)

POP, FJ 1962. De tweede brief van Paulus aan de Corinthiërs. 2de herziene druk. Nijkerk: Callenbach. (PNT.)

REHKOPF, F 1976. See under Blass, F, Debrunner, A \& Rehkopf, F. 
REICHENBACH, BR 1977. Resurrection of the body, re-creation and interim existence. IThSA 21, 33-42.

REICKE, B 1965. Body and soul in the New Testament. St Th 19, 200-212.

RIDDERBOS, H 1975. Paul. An outline of his theology. Tr by JR de Witt. Grand Rapids: Eerdmans.

RISSI, M 1969. Studien zum zweiten Korintherbrief. Der alte Bund - der Prediger - der Tod. Zürich: Zwingli Verlag.

ROBERTSON, AT 1930. Word pictures in the New Testament. Vol 2, The Gospel according to Luke. Nashville: Broadman.

ROBERTSON, AT 1931. Word pictures in the New Testament. Vol 4, The epistles of Paul. Nashville: Broadman.

ROBERTSON, AT 1934. A grammar of the Greek New Testament in the light of historical research. Nashville: Broadman.

ROBINSON, JAT 1952. The body. A study in Pauline theology. London: SCM.

ROBINSON, TH 1928. The Gospel of Matthew. London: Hodder \& Stoughton. (MNTC.)

RUSSELL, BAW 1954. History of Western philosophy. London: Allen \& Unwin.

SCHÄFER, P 1984. New Testament and Hekhalot literature: The journey into heaven in Paul and in Merkavah mysticism. IJS 35, 19-35.

SCHENK, W 1984. Die Philipperbriefe des Paulus. Stuttgart: Kohlhammer.

SCHWEITZER, A 1954. Die Mystik des Apostels Paulus. 2. Aufl. Tübingen: Mohr.

SCHWEIZER, E 1957. Die hellenistische Komponente im neutestamentlichen sárxBegriff. ZNW 48, 237-253.

SCHWEIZER, E 1959. sv pneûma, ktl. ThWNT VI, 387-453.

SEVENSTER, JN 1955. Einige Bemerkungen über den 'Zwischen-zustand' bei Paulus. NTS 1, 291-296.

SIZOO, A 1923. Het spotten der Atheners met de opstanding der dooden. GTT 24, $289-297$.

SJÖBERG, E 1959. sv pneûma, ktl. ThWNT VI, 373-387.

STACEY, WD 1956. The Pauline view of man. London: Macmillan.

STAUFFER, E 1955. New Testament theology. Tr by J Marsh. London: SCM.

STRACK, HL \& Billerbeck, P 1924. Kommentar zum neuen Testament aus Talmud und Midrasch. Bd 2, Das Evangelium nach Markus, Lukas, und Johannes und die Apostelgeschichte. München: Beck.

STRACK, HL \& Billerbeck, P 1926. Kommentar zum neuen Testament aus Talmud und Midrasch. Bd 3, Die Briefe des neuen Testaments und die Offenbarung Johannis. München: Beck.

STRACK, HL \& Billerbeck, P 1955. Kommentar zum neuen Testament aus einzelnen Stellen des Neuen Testaments. Abhandlungen zur neutestamentlichen Theologie und Archäologie. München: Beck.

SWETE, HB [1898] 1909. The Gospel according to St Mark. 3rd ed. London: Macmillan.

TASKER, RVG 1958. The second epistle of Paul to the Corinthians. Leicester: IVP. (TNTC.)

TAYLOR, V 1952. The Gospel according to St Mark. London: Macmillan.

TRENCH, RC [1897] 1978. Commentary on the epistles to the seven churches in Asia. Revelation IL III. 6th ed. Reprint. Minneapolis: Klock \& Klock.

TURNER, N 1963. A grammar of New Testament Greek, Vol 3. Syntax Edinburgh: Clark.

UBBINK, JTh 1917. Het eeuwige leven bij Paulus. Een godsdienst-historisch onderzoek. DD Thesis. Rijks University of Groningen.

VAN DER LEEUW, G 1933. Phänomenologie der Religion. Tübingen: Mohr.

VINCENT, MR [1887] 1957a. Word studies in the New Testament. Vol 1, The synoptic gospels, acts of the apostles, epistles of Peter, James, and Jude. Reprint. Grand Rapids: Eerdmans.

VINCENT, MR [1887] 1957b. Word studies in the New Testament. Vol 3, The epistles of Paul. Reprint. Grand Rapids: Eerdmans.

VÖLKEL, M 1981. sv koimáomai, ktl. ThWNT II, 745-746. 
VOLZ, P 1934. Die Eschatologie der jüdischen Gemeinde im neutestamentlichen Zeitalter. 2. Aufl. Tübingen: Mohr.

VON DOBSCHÜTZ, E [1909] 1974. Die Thessalonicker-Briefe. Hrsg von F Hahn. Nachdruck. Göttingen: Vandenhoeck.

WARD, WB 1943. The intermediate state. A study of the teachings of Jesus. UTSR 54, $230-244$.

WENDLAND, H-D 1978. Die Briefe an die Korinther. 14. Aufl. Göttingen: Vandenhoeck. (NTD 7.)

WHITELEY, DEH 1974. The theology of St Paul. 2nd ed. Oxford: Blackwell.

WINDISCH, H 1924. Der zweite Korintherbrief. 9. Aufl. Göttingen: Vandenhoeck. (KEK 6.)

WOHLENBERG, G 1909. Der erste und zweite Thessalonicherbrief. 2. Aufl. Leipzig: Deichert. (KNT 12.)

WOHLENBERG, G 1910. Das Evangelium des Markus. Leipzig: Deichert. (KNT 2.)

ZAHN, Th 1910. Das Evangelium des Matthäus. 3. Aufl. Leipzig: Deichert. (KNT 1.)

ZAHN, Th 1913. Das Evangelium des Lucas. Leipzig: Deichert. (KNT 3.) 